\title{
Groundwater-dependent ecosystems: recent insights from satellite and field-based studies
}

\author{
D. Eamus ${ }^{1,2}$, S. Zolfaghar ${ }^{1,2}$, R. Villalobos-Vega ${ }^{1,2}$, J. Cleverly ${ }^{2}$, and A. Huete ${ }^{2}$ \\ ${ }^{1}$ National Centre for Groundwater Research and Training, University of Technology Sydney, P.O. Box 123, \\ Sydney, NSW 2007, Australia \\ ${ }^{2}$ School of Life Sciences, University of Technology Sydney, P.O. Box 123, Sydney, NSW 2007, Australia \\ Correspondence to: D. Eamus (derek.eamus@uts.edu.au)
}

Received: 9 March 2015 - Published in Hydrol. Earth Syst. Sci. Discuss.: 4 May 2015

Revised: 30 September 2015 - Accepted: 30 September 2015 - Published: 21 October 2015

\begin{abstract}
Groundwater-dependent ecosystems (GDEs) are at risk globally due to unsustainable levels of groundwater extraction, especially in arid and semi-arid regions. In this review, we examine recent developments in the ecohydrology of GDEs with a focus on three knowledge gaps: (1) how do we locate GDEs, (2) how much water is transpired from shallow aquifers by GDEs and (3) what are the responses of GDEs to excessive groundwater extraction? The answers to these questions will determine water allocations that are required to sustain functioning of GDEs and to guide regulations on groundwater extraction to avoid negative impacts on GDEs.

We discuss three methods for identifying GDEs: (1) techniques relying on remotely sensed information; (2) fluctuations in depth-to-groundwater that are associated with diurnal variations in transpiration; and (3) stable isotope analysis of water sources in the transpiration stream.

We then discuss several methods for estimating rates of GW use, including direct measurement using sapflux or eddy covariance technologies, estimation of a climate wetness index within a Budyko framework, spatial distribution of evapotranspiration (ET) using remote sensing, groundwater modelling and stable isotopes. Remote sensing methods often rely on direct measurements to calibrate the relationship between vegetation indices and ET. ET from GDEs is also determined using hydrologic models of varying complexity, from the White method to fully coupled, variable saturation models. Combinations of methods are typically employed to obtain clearer insight into the components of groundwater discharge in GDEs, such as the proportional importance of
\end{abstract}

transpiration versus evaporation (e.g. using stable isotopes) or from groundwater versus rainwater sources.

Groundwater extraction can have severe consequences for the structure and function of GDEs. In the most extreme cases, phreatophytes experience crown dieback and death following groundwater drawdown. We provide a brief review of two case studies of the impacts of GW extraction and then provide an ecosystem-scale, multiple trait, integrated metric of the impact of differences in groundwater depth on the structure and function of eucalypt forests growing along a natural gradient in depth-to-groundwater. We conclude with a discussion of a depth-to-groundwater threshold in this mesic GDE. Beyond this threshold, significant changes occur in ecosystem structure and function.

\section{Introduction}

Water stored below ground in the saturated zone (groundwater) is the largest global store of liquid freshwater, accounting for about $96 \%$ of all liquid freshwater (Shiklomanov, 2008). Whilst readily accessed by humans for millennia at naturally occurring springs/oases and as baseflow discharge into rivers, it has only been during the past 100 years that exploitation of groundwater resources has become of global concern (Gleick and Palaniappan, 2010). The rate of groundwater use of three (Pakistan, Iran and Saudi Arabia) of the seven largest users of groundwater (India, the USA, Pakistan, China, Iran, Mexico and Saudi Arabia) use groundwater at an annual rate that exceeds the renewable resource volume (Giordano, 2009). Only three of the top 10 users are OECD members, reflecting 
the large reliance on groundwater of less developed nations, which are often located in arid and semi-arid climates where surface water stores are generally low.

About two-fifths of the world's terrestrial surface area is arid or semi-arid and more than $38 \%$ of the world's population lives there. Managing groundwater resources sustainably is therefore a major global social and economic priority (Glazer and Likens, 2012). Whilst about $40 \%$ of global groundwater abstraction occurs in these regions, the scarcity of rain means that only $2 \%$ of groundwater recharge occurs there (Wada et al., 2010). Water is increasingly becoming a geopolitical and strategic resource. Disputes between neighbouring states are increasing as demands for groundwater increase. Because of the close relationship between crop yield and water supply, diminishing availability of groundwater in arid and semi-arid regions has immediate and severe impacts on food supplies, food prices and concomitant social unrest. Recent estimates suggest that between 10 and $25 \%$ of the food produced in China and India (home to 2.5 billion people) is at risk because of groundwater depletion (Seckler et al., 1999; Brown, 2007).

Over-extraction of groundwater stores can create several problems. These include loss of discharge from groundwater to wetlands, springs and streams/rivers, which results in loss of ecosystem structure and function and the associated loss of ecosystem services (Eamus et al., 2006a; Murray et al., 2006); increased depth of groundwater, thereby reducing its availability within the root zone of terrestrial groundwaterdependent vegetation; reduced availability of groundwater for direct human consumption; and reduced availability of groundwater for commercial use, including irrigation, stock watering and other industrial applications.

In a recent wide-ranging review of groundwater-dependent ecosystems (GDEs), Orellana et al. (2012) identified quantification of the water used by GDEs and an understanding of the physiology of GDEs as major unresolved problems. Naumburg et al. (2005) provide a review of the impact of both declining and increasing depth to the water table on phreatophytic vegetation in arid zones and provide two conceptual models describing ecosystem responses to these changes in depth. They note that information on root depth and the impact this may have on responses to changes in depth-to-groundwater as a key knowledge gap. In this current review we discuss application of remote sensing techniques to quantify rates of water use of GDEs. We present ecophysiological responses of vegetation to differences in groundwater availability in two case studies plus the results of a 4year ecophysiological study of eucalypt woodlands across a natural gradient in depth-to-groundwater in a mesic environment. From this last study we produce an integrated response metric for the response of these woodlands to differences in groundwater depth.

Whilst Hatton and Evans (1998) recognised five classes of ecosystem dependency on groundwater, we use the simplified classification system proposed by Eamus et al. (2006b):
1. Aquifer and cave ecosystems where stygofauna reside. This class also includes the hyporheic zones of rivers and floodplains.

2. Ecosystems reliant on the surface expression of groundwater. This includes springs, estuarine seagrasses, and base-flow rivers, streams and wetlands.

3. Ecosystems reliant on sub-surface presence of groundwater within the rooting depth of the ecosystem (usually via the capillary fringe).

Application of this simple classification scheme assists managers in identifying the correct techniques for assessing GDE structure, function and management regime (Eamus et al., 2006b), and this classification scheme was recently adopted in the Australian National Atlas of Groundwater-Dependent Ecosystems.

In this review, we focus on the ecohydrology of groundwater-dependent ecosystems rather than on groundwater resources per se. This is because we feel that environmental allocations of groundwater have generally received less attention than allocations to human demands and because we identify three important knowledge gaps in the sustainable management of groundwater for environmental allocations. These are the following:

1. How do we know where a groundwater-dependent ecosystem (GDE) is in the landscape? If we do not know where they are, we cannot manage them and allocate groundwater resources appropriately.

2. How much groundwater is used by a GDE? If we do not know how much groundwater is used, we cannot allocate an appropriate quantity of the resource.

3. What are the likely responses of GDEs to overextraction of groundwater? Without knowing what to measure, we cannot regulate groundwater extraction in ways that do not negatively impact on GDEs.

\section{Identifying groundwater-dependent vegetation}

Identifying the location of GDEs is the first requisite step to managing them. However, identifying their location across a landscape is difficult, time-consuming, expensive and requires a high level of technical expertise. In this section, a range of new techniques that can be used to assist in this are discussed.

\subsection{Methods to identify GDEs: indirect inference}

Early assessments of groundwater dependency generally relied on inference (Eamus et al., 2006a; Clifton and Evans, 2001). Recent applications of inferential techniques to springs, wetland, rivers and lakes can be found in Brown et al. (2010) and to springs, wetlands and streams reliant on 
baseflow in Howard and Merrifield (2010) and are not further discussed here.

\subsection{Direct methods}

\subsubsection{Satellite-based approaches}

In recent years remote sensing (RS) of land surfaces and vegetation structure (e.g. phenology, LAI) and function (e.g. ET, gross primary productivity) has become increasingly sophisticated (Glenn et al., 2010; Yuan et al., 2010; Jung et al., 2011; Rossini et al., 2012; Kanniah et al., 2013; Ma et al., 2013; Nagler et al., 2013) and increasingly applied to realworld applications of water resources management (Scott et al., 2008; Glenn et al., 2010; Barron et al., 2014; Doody et al., 2014). Remote sensing (RS) provides a robust and spatially explicit means to assess not only vegetation structure and function but also relationships amongst these and climate variables.

A key concept in the development of RS applications for identifying the location of GDEs is that of "green islands" (Everitt and DeLoach, 1990; Everitt et al., 1996; Neale, 1997; Akasheh et al., 2008), which began with the airborne observations of desert oases and riparian corridors. In this model the structure or function of one pixel in an RS image is compared to that of another pixel located nearby. If one pixel contains a GDE but the other does not, the hypothesis that the structure and function of vegetation in the two pixels will diverge during extended dry periods can be tested. The underlying assumption is that vegetation with access to groundwater will not be subject to the same degree of soil water deficit as vegetation that does not have access to groundwater; thus, the spectral signature of the two pixels will diverge over time. By comparing vegetation structure or function across contrasting periods (e.g. comparisons across "wet" and "dry" periods) or across landscapes (e.g. comparisons from riverside to upland pixels), green islands within a sea of browning vegetation can be identified (Contreras et al., 2011).

Münch and Conrad (2007) used Landsat imagery to identify the presence/absence of wetlands across three catchments in South Africa. They combined this with GIS terrain modelling to determine whether GDEs could be identified using a landscape "wetness potential" for class II GDEs (those reliant on a surface expression of groundwater). They concluded that RS data could be used to classify landscapes by comparing the attributes of potential GDEs to the attributes of surrounding land covers during three periods: in July when rains started at the end of a dry year; in August during the winter of a wet year; and at the end of a dry summer. When this was combined with a GIS model using landscape characteristics, they were able to produce a regional-scale map of the distributions of GDEs.

Plant density is often correlated with water availability, especially in arid and semi-arid regions. Thus, plant density tends to be larger when groundwater is available than

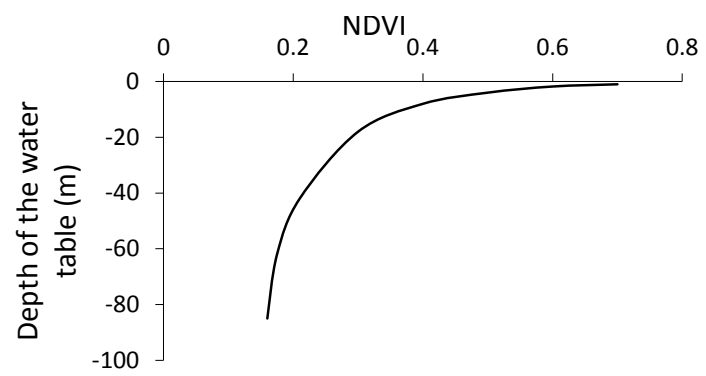

Figure 1. The relationship between NDVI and depth to the water table for the Hailiutu River catchment in northern China. Redrawn from Lv et al. (2012).

in nearby vegetation that does not have access to groundwater. Lv et al. (2012) used a remotely sensed vegetation index (normalised difference vegetation index; NDVI; $300 \mathrm{~m}$ resolution) to examine changes in depth-to-groundwater within a small region in northern China. NDVI is a reliable measure of the chlorophyll content ("greenness") in leaves and vegetation cover (Gamon et al., 1995; Carlson and Ripley, 1997; Huete et al., 2002). Using a $25 \mathrm{~m}$ resolution digital elevation model and groundwater bore data, the resultant relationship between NDVI and depth-to-groundwater was obtained (Fig. 1).

Similar in shape to the relationship between LAI and NDVI, the largest values of NDVI occurred at sites with shallow groundwater and declined curvi-linearly as depthto-groundwater increased. In that study, a cut-off of approximately $10 \mathrm{~m}$ depth-to-groundwater was identified below which vegetation cover was relatively insensitive to further increase in groundwater depth. In contrast, the threshold was about $4.4 \mathrm{~m}$ depth-to-groundwater in the Ejina area of north-western China (Jin et al., 2011). In their study, which included part of the Gobi desert where annual rainfall was about $40 \mathrm{~mm}$, vegetation was absent in regions where groundwater depth exceeded $5.5 \mathrm{~m}$. They also used NDVI and 13 groundwater bores, from which relationships between NDVI and groundwater depth for three vegetation classes (grassland, woodland and scrubland) were established. Maximal values of NDVI occurred at sites with intermediate (2.5$3.5 \mathrm{~m}$ ) depth-to-groundwater rather than at sites with shallower groundwater, a result often ascribed to the effect of anoxia arising from root flooding when the water table is too shallow (Naumburg et al., 2005).

Geological, hydrological and ecological data can be used to define areas that have common physical and climatic profiles. These regions are expected to have similar vegetation cover (assuming no management has induced significant changes); thus, such areas are expected to have a similar RS signature. Dresel et al. (2010) applied this approach for individual regions in South Australia by developing a correlation analysis using Landsat summer NDVI and the MODIS enhanced vegetation index (EVI) as surrogate measures of 
productivity. EVI is effective for scaling productivity across the range of global ecosystem types (Campos et al., 2013). MODIS EVI images were used to identify regions displaying a consistent photosynthetic activity throughout the year. Landsat NDVI images were then used to locate areas displaying large inter-annual variation in photosynthetic activity across wet and dry years, which were identified by aridity thresholds that were calculated from the Thornthwaite index. Finally, they used an unsupervised classification of Landsat spectral data to locate pixels with similar spectral signatures of areas corresponding to known groundwaterdependent ecosystems. Species-specific differences in spectral signatures have been identified previously (Nagler et al., 2004). By combining all three sources of information (geological, hydrological and ecological) within a GIS, Dresel et al. (2010) identified all pixels across a catchment that had a very high probability of being a GDE. Critical for providing assurance of accurate mapping, ground reconnaissance ("truthing") was used to validate these findings.

Mapping of groundwater discharge zones (that is, discharge through transpiration and to the ground surface) provides an alternative approach to finding GDEs. Discharge of groundwater has a large effect on local ecology. To define the spatial extent of discharge, information is required about the geology, hydrology, ecology and climate of a site (Tweed et al., 2007). By using thermal, Landsat optical and MODIS NDVI data coupled to digital elevation models and depth-togroundwater data, Leblanc et al. (2003a, b) located discharge areas in the semi-arid Lake Chad basin in Africa. Similarly, Tweed et al. (2007) examined discharge (and recharge) of the Glenelg-Hopkins catchment in south-eastern Australia. Discharge occurred through direct evaporation from the water table (i.e. groundwater evaporation); groundwater transpiration; and discharge to the ground surface at landscape depressions, rivers, wetlands and break-of-slope localities. Importantly, they observed low variability of vegetation activity across wet and dry periods (seasons or years) using the NDVI as a measure of vegetation. In this case, the variability in NDVI was correlated with locations where groundwater was supporting vegetation activity. One possible limitation to this method is that it tends to be most accurate in more xeric locations, where rainfall is more likely to limit vegetation function, except during extended droughts in mesic environments.

\subsubsection{Fluctuations in groundwater depth}

When rooting depth is sufficient, vegetation can directly access the water table via the capillary zone of shallow unconfined aquifers. In some circumstances groundwater uptake by vegetation can be seen as a diel fluctuation in the depth-to-groundwater (Miller et al., 2010), as first identified in groundwater hydrographs by White (1932). These daily fluctuations in depth-to-groundwater cease when the water table falls below the rooting zone (Butler et al., 2007) or when vegetation is dormant (Lautz, 2008; Martinet et al., 2009; Miller et al., 2010). However, changes in the density of water with temperature can cause expansion and contraction of an aquifer (Post and von Asmuth, 2013), leading to the erroneous conclusion that the vegetation is accessing groundwater. Additionally, when the water table is very shallow, direct evaporation from groundwater via bare soil can be substantial (1-10 mm day ${ }^{-1}$ ) (Thorburn et al., 1992) and this may also be misinterpreted. Thus, groundwater dependency generally requires supporting confirmation from multiple indicators and cannot be identified definitively from the White method alone. Further elaboration of the White method is given in Sect. 3.5.1 and described in detail in Orellana et al. (2012).

\subsubsection{Stable isotope analysis}

Direct evidence that vegetation is using groundwater can be obtained by comparing the stable isotope composition of groundwater, soil water, surface water (if relevant) and xylem water (Thorburn et al., 1993; Zencich et al., 2002; Lamontagne et al., 2005; O'Grady et al., 2006a, b; Kray et al., 2012; Busch et al., 1992; Ehleringer and Dawson, 1992; Smith et al., 1998). This method is very effective in semi-arid regions where groundwater is derived from snowmelt or winter precipitation (which is isotopically lighter than summer precipitation) (Ehleringer and Dawson, 1992; Smith et al., 1998; Jobbagy et al., 2011). When sufficient differences in isotopic composition exist among sources of water, the dominant source used by different species at different times of year can be identified (Zencich et al., 2002).

An example of deuterium isotope analysis of water collected from xylem, soil, river and groundwater is shown in Table 1. Species growing close to groundwater (Melaleuca argentea) have xylem isotope compositions close to that of groundwater but species growing further upslope away from the river had xylem isotope compositions close to that of soil water isotope. Further examples include (a) identification of soil and surface water use by juvenile riparian plants, in contrast to groundwater use by mature trees (Dawson and Ehleringer, 1991); and (b) determination of the mountainous source of groundwater and opportunistic use of that groundwater by riparian trees (Chimner and Cooper, 2004).

Mixed-member models (i.e. "Keeling plots") can be applied to allow estimation of the relative contribution of multiple sources of water to the water absorbed by roots (Phillips and Greg, 2003). While it is possible for a linear mixing model to distinguish more than two potential sources of water, such an application requires the fractionation of ${ }^{2} \mathrm{H}$ or ${ }^{18} \mathrm{O}$ to be independent of each other, which is often not the case. At a minimum, the use of stable isotopes can provide information about spatial and temporal variation in groundwater dependency across species and ecosystems. Application of stable isotope analyses to quantify the rate of water use is discussed later (Sect. 3.5.2). 
Table 1. Deuterium analysis of xylem, soil, river water and groundwater in a study of three species growing in the Northern Territory of Australia. The $\delta^{2} \mathrm{H}$ values (\%o) of soil became more negative as distance from groundwater increased due to enrichment during surface evaporation. At shallow sites (Melaleuca argentea) the groundwater is near the surface and xylem water $\delta^{2} \mathrm{H}$ values match soil water and groundwater. As depth-to-groundwater increased (because of local topography: the site slopes up from the river) xylem water isotope composition was increasingly more negative than groundwater because groundwater was unavailable to the roots. From Lamontagne et al. (2005).

\begin{tabular}{lllccc}
\hline & $\begin{array}{l}\text { Depth-to- } \\
\text { groundwater } \\
(\mathrm{m})\end{array}$ & $\begin{array}{l}\text { River } \\
\text { water }\end{array}$ & $\begin{array}{c}\text { Soil } \\
\text { water }\end{array}$ & $\begin{array}{c}\text { Xylem } \\
\text { water }\end{array}$ & Groundwater \\
\hline Daly River & 0 & -44 & & & \\
M. argentea & $<0.25$ & & -44 & -43 to -48 & -43 \\
B. acutangula & 3 & & -80 & -46 to -40 & -45 \\
C. bella & $>15$ & & -56 to -91 & -59 to -71 & Not available to roots \\
\hline
\end{tabular}

\section{Application of remote sensing to the study of GDEs}

\subsection{A primer on remote sensing derived values of rates of water flux}

Before discussing the application of RS techniques to estimate rates of groundwater use by vegetation, we will provide a simple summary of the principles of using RS to estimate ET more broadly. For a detailed and comprehensive evaluation of these methods, refer to Glenn et al. (2007). Table 2 provides examples of recent studies that have used RS in the study of GDEs.

The energy balance equation for land surfaces is

$\mathrm{LE}+H=R_{\mathrm{n}}-G$,

where LE is latent energy flux (that is, ET), and $H$ is sensible heat flux. $R_{\mathrm{n}}$ is net radiation and $G$ is soil heat flux. Differences in temperature between air temperature and canopy temperature have been used to estimate sensible heat flux (Glenn et al., 2010). Using the reasonable assumption that $G$ averages out to zero over any single $24 \mathrm{~h}$ period and $R_{\mathrm{n}}$ is either measured or derived from remote sensing data, then LE (that is, ET) can be calculated by difference.

Li and Lyons (1999) compared three methods that use surface temperatures to estimate ET. In two methods, differences in surface and air temperature were used to estimate ET, although the two methods differed in the details of the aerodynamic resistance functions. The third model combined NDVI, surface temperature and a soil-adjusted vegetation index that required the four extreme values of surface temperature and NDVI to be located simultaneously within the study area (i.e. patches of dry bare soils; wet bare soil; wet, fully vegetated patches; and dry, water stressed, fully vegetated surfaces). This can make its application problematic. Two methods used the energy balance equation to estimate ET, whereas ET was estimated in a third by using RS data to estimate the Priestley-Taylor factor that scales between ET and potential ET $\left(\mathrm{ET}_{\mathrm{p}}\right)$. They concluded that the simplest first and second models produced better estimates of ET and that inclusion of the soil index improved the estimates of ET from native (i.e. non-agricultural) vegetation. Likewise, Nagler et al. (2005a, b) found that estimates of ET from riparian corridors using RS were improved with the incorporation of a soil index.

\subsection{Estimating groundwater use by remote sensing}

Quantifying the water balance of arid and semi-arid landscapes and aquifers is important to sustainably manage water resources. Accurate and spatially distributed estimates of discharge through vegetation are difficult to obtain through field measurements. Recently, RS methods have been calibrated against Penman-Monteith estimates of ET (Glenn et al., 2010; Nagler et al., 2013; Doody et al., 2014), which requires only standard weather data (net radiation, wind speed and vapour pressure deficit) and thus increases the coverage of calibration sites. Because ET in GDEs is generally not limited by soil moisture when groundwater is of high quality (i.e. not saline), it is assumed that actual ET rates are equivalent to the ET of a reference grass crop (i.e. reference ET, $\mathrm{ET}_{0}$ ), as computed following FAO-56 (Allen et al., 1998). Then, normalised VIs, either EVI* or NDVI*, can be used like crop coefficients to estimate the spatial distribution of $\mathrm{ET}_{\mathrm{a}}$ from $\mathrm{ET}_{0}$ on a per-pixel basis. Nagler et al. (2013) used an exponential scaling function of $\mathrm{EVI}^{*}$ to estimate $\mathrm{ET}_{\mathrm{a}}$ :

$\mathrm{ET}_{\mathrm{a}}=\mathrm{ET}_{0}\left(a\left[1-e^{-b \mathrm{EVI}^{*}}\right]-c\right)$

Similarly, Groeneveld and Baugh (2007) found that this methodology is particularly applicable to arid and semi-arid vegetation underlain by a shallow water table. In arid and semi-arid regions, annual rainfall is low and often erratic. Consequently, the presence of a shallow water table results in a relatively consistent supply of water to roots. NDVI* was calculated from summer peak season NDVI (Groeneveld and Baugh, 2007): 
Table 2. Some examples of the application of remote sensing to the study of groundwater-dependent ecosystems.

\begin{tabular}{|c|c|c|}
\hline Notes on methods & Application & Reference \\
\hline $\begin{array}{l}\text { eVI (MODIS) + MODIS land } \\
\text { surface temp + water balance } \\
\text { equation }\end{array}$ & $\begin{array}{l}\text { Calibrated, empirical model of } \\
\text { riparian ET; groundwater use } \\
\text { quantified from } \mathrm{ET}_{\mathrm{g}}=\mathrm{ET}-(P-\Delta S)\end{array}$ & $\begin{array}{l}\text { Scott et al., } \\
(2008)\end{array}$ \\
\hline $\begin{array}{l}\text { eVI (MODIS) + empirical } \\
(2012) \\
\text { relationship of ET, eVI and } \mathrm{ET}_{\mathrm{o}}\end{array}$ & $\begin{array}{l}\text { Calibrated, empirical model of } \\
\text { riparian ET; groundwater use } \\
\text { quantified }\end{array}$ & Tillman et al. \\
\hline $\begin{array}{l}\text { "Green island method": } \\
\text { calculate standard deviation in } \\
\text { NDVI across 14-year pixel } \\
\text { by pixel }\end{array}$ & $\begin{array}{l}\text { Identifying location of GDEs by } \\
\text { determining where veg activity } \\
\text { shows minimal seasonal variation }\end{array}$ & $\begin{array}{l}\text { Tweed et al. } \\
\text { (2007) }\end{array}$ \\
\hline $\begin{array}{l}\text { "Green island method": } \\
\text { calculate standard deviation in } \\
\text { eVI across years and seasonally }\end{array}$ & $\begin{array}{l}\text { Identifying location of GDEs by } \\
\text { determining where veg activity } \\
\text { shows minimal seasonal/inter } \\
\text { annual variation }\end{array}$ & $\begin{array}{l}\text { Dresel et al. } \\
(2010)\end{array}$ \\
\hline $\begin{array}{l}\text { "Green island method": } \\
\text { calculate LAI for adjacent } \\
\text { pixels; find regions with larger } \\
\text { LAI with GW access }\end{array}$ & $\begin{array}{l}\text { Identifying location of GDEs by } \\
\text { determining larger LAI }\end{array}$ & $\begin{array}{l}\text { Colvin et al. } \\
(2007)\end{array}$ \\
\hline $\begin{array}{l}\text { NDVI (MODIS) + groundwater } \\
\text { depth from bore data }\end{array}$ & $\begin{array}{l}\text { Relationship between GW depth } \\
\text { and vegetation cover }\end{array}$ & $\begin{array}{l}\text { Jin et al. } \\
\text { (2011) }\end{array}$ \\
\hline $\begin{array}{l}\text { NDVI (MODIS) + groundwater } \\
\text { depth from bore data }\end{array}$ & $\begin{array}{l}\text { Relationship between GW depth } \\
\text { and vegetation cover }\end{array}$ & $\begin{array}{l}\text { Lv et al. } \\
(2012)\end{array}$ \\
\hline $\begin{array}{l}\text { Surface energy balance } \\
(2008,2011) \\
\text { (SEBAL) + Landsat surface } \\
\text { temp; LAI derived from MODIS }\end{array}$ & $\begin{array}{l}\text { Estimating ET from GDEs at pixel- } \\
\text { by-pixel resolution }\end{array}$ & Yang et al. \\
\hline SEBAL + NDVI (MODIS) & Estimating ET at $90 \mathrm{~m}$ resolution & $\begin{array}{l}\text { Bindhu et al. } \\
\text { (2013) }\end{array}$ \\
\hline SEBAL + MODIS & Estimating ET & $\begin{array}{l}\text { Tang et al. } \\
\text { (2013) }\end{array}$ \\
\hline $\begin{array}{l}\text { SEBAL + SWAT model } \\
\text { (hydrology) }\end{array}$ & Estimating groundwater recharge & $\begin{array}{l}\text { Githui et al. } \\
\text { (2012) }\end{array}$ \\
\hline SEBAL + LANDSAT images & $\begin{array}{l}\text { Estimating arid zone shallow } \\
\text { aquifer discharge }\end{array}$ & $\begin{array}{l}\text { Matic et al. } \\
\text { (2011) }\end{array}$ \\
\hline $\begin{array}{l}\text { Penman-Monteith equation with } \\
\text { RS estimates of LAI, NDVI and } \\
\text { used to estimate land surface } \\
\text { conductance }\end{array}$ & km-scale estimates of ET & $\begin{array}{l}\text { Cleugh et al. } \\
\text { (2007) }\end{array}$ \\
\hline $\begin{array}{l}\text { EVI }+ \text { surface temperature }+ \\
\text { canopy fractional cover }\end{array}$ & $\begin{array}{l}\text { Partitions ET into vegetation and } \\
\text { soil components }\end{array}$ & $\begin{array}{l}\text { Mu et al. } \\
\text { (2007) }\end{array}$ \\
\hline $\begin{array}{l}\left.\mathrm{ET}_{\mathrm{a}}^{*}=\mathrm{ET}_{\mathrm{a}}-\text { rainfall }\right) /\left(\mathrm{ET}_{\mathrm{o}}-\right. \\
\text { rainfall) } \\
\mathrm{ET}_{\mathrm{a}} \text { linearly correlated with } \\
\mathrm{NDVI}^{*} \\
\left.\mathrm{ET}_{\mathrm{g}}=\mathrm{ET}_{0}-\text { rainfall }\right) \mathrm{NDVI}^{*}\end{array}$ & $\begin{array}{l}\text { Estimated GW use }\left(\mathrm{ET}_{\mathrm{g}}\right) \text { rather } \\
\text { than } \mathrm{ET}_{\mathrm{a}}\end{array}$ & $\begin{array}{l}\text { Groeneveld } \\
(2008)\end{array}$ \\
\hline $\begin{array}{l}\text { MODIS veg indices compared; } \\
\text { PM equation used to find } G_{\mathrm{c}} \\
\text { and regress } G_{\mathrm{c}} \text { against MODIS veg } \\
\text { indices }\end{array}$ & Estimate $\mathrm{ET}_{\mathrm{a}}$ and $G_{\mathrm{c}}$ & $\begin{array}{l}\text { Yebra et al. } \\
(2013)\end{array}$ \\
\hline $\begin{array}{l}\text { MODIS reflectance }+ \text { residual } \\
\text { moisture index (from eVI) }+ \\
\text { global veg moisture index } \\
\text { Actual ET calculated from } \\
\text { PET } \cdot \text { crop factor and crop factor } \\
\text { is derived from EVI }\end{array}$ & $\begin{array}{l}\text { Estimate ET at } 1 \mathrm{~km} \text { spatial } \\
\text { resolution }\end{array}$ & $\begin{array}{l}\text { Guerschman } \\
\text { et al. (2009) }\end{array}$ \\
\hline
\end{tabular}


$\mathrm{NDVI}^{*}=\left(\mathrm{NDVI}-\mathrm{NDVI}_{z}\right) /\left(\mathrm{NDVI}_{m}-\mathrm{NDVI}_{z}\right)$,

where $\mathrm{NDVI}_{z}$ and $\mathrm{NDVI}_{m}$ are the NDVI values for zero vegetation cover and NDVI at saturation, respectively. Although selection of the values for $\mathrm{NDVI}_{z}$ and $\mathrm{NDVI}_{m}$ can introduce uncertainty, Groeneveld and Baugh (2007) found significant convergence in the NDVI by removal of non-systematic scatter in the data. Calibration of ET in the field is not required to apply this method, but it is necessary to define $\mathrm{NDVI}_{m}$. This requires highly verdant pixels in the RS images, arising either from irrigation or the presence of, for example, riparian vegetation that maintains a large LAI. At mesic sites, defining $\mathrm{NDVI}_{z}$ may also be difficult. Despite these problems, Groeneveld and Baugh (2007) were able to disaggregate the influence of groundwater supply from that of recent rainfall.

Groeneveld et al. (2007) applied this NDVI* methodology to three arid sites in the US where annual $\mathrm{ET}_{\mathrm{a}}$ values were available through the availability of Bowen ratio or eddy covariance measurements. A significant linear relationship $\left(R^{2}=0.94\right)$ was found between measured annual $\mathrm{ET}_{\mathrm{a}}$ and mid-summer NDVI ${ }^{*}$, despite very different vegetation composition and structure across those sites. However, the regression of $\mathrm{ET}_{\mathrm{a}} / \mathrm{ET}_{0}$ versus NDVI* did not pass through the origin and would introduce an offset error if NDVI* were used to estimate $\mathrm{ET}_{\mathrm{a}}$. To overcome this, Groeneveld et al. (2007) transformed $\mathrm{ET}_{\mathrm{a}}$ to $\mathrm{ET}_{\mathrm{a}}^{*}$ :

$\mathrm{ET}_{\mathrm{a}}^{*}=\left(\mathrm{ET}_{\mathrm{a}}-\right.$ rainfall $) /\left(\mathrm{ET}_{0}-\right.$ rainfall $)$.

The resulting regression of $\mathrm{ET}_{\mathrm{a}}^{*}$ versus $\mathrm{NDVI}^{*}$ yielded a slope of 0.97 , an intercept of zero and an $R^{2}$ of 0.96 . They concluded that $\mathrm{NDVI}^{*}$ was a reliable indicator of $\mathrm{ET}_{\mathrm{a}}^{*}$. Rearranging the equation above and substituting $\mathrm{NDVI}^{*}$ for $\mathrm{ET}_{\mathrm{a}}^{*}$, they demonstrated that

$\mathrm{ET}_{\mathrm{a}}($ estimated $)=\left(\mathrm{ET}_{0}-\right.$ rainfall $) \mathrm{NDVI}^{*}+$ rainfall.

They estimated the amount of groundwater transpired $\left(\mathrm{ET}_{\mathrm{g}}\right)$ by deducting annual rainfall from annual $\mathrm{ET}_{\mathrm{a}}$. That is, $\mathrm{ET}_{\mathrm{g}}=\left(\mathrm{ET}_{0}-\right.$ rainfall $) \mathrm{NDVI}^{*}$. The average error in $\mathrm{ET}_{\mathrm{g}}$ was estimated to be about $12 \%$, which in the absence of field measurements is a very valuable estimate of rates of groundwater use. Further application of the Groeneveld et al. (2007) method can be found in Groeneveld (2008).

\section{Up-scaling from point to larger-scale estimates of ET}

Riparian vegetation is often reliant on groundwater (either through bank recharge or direct access to the shallow water table), especially in arid and semi-arid regions. Rates of ET are enhanced by groundwater use in dry environments (Cleverly, 2013), where riparian ET is a large component of the water balance (Dahm et al., 2002; Scott et al., 2008). However, measurement of the riparian ET component depends upon the physical characteristics of the riparian corridor. If a riparian corridor is sufficiently wide, eddy covariance can be used to directly measure ET (Cleverly, 2013). Where the corridor is insufficiently wide, tree-scale sap flow techniques can be used (O'Grady et al., 2006; Goodrich et al., 2000b). Combinations of both methods (Moore et al., 2008; Oishi et al., 2008) can be used to partition transpiration from evapotranspiration (Scott et al., 2006a), thereby estimating the proportion of ET due to transpiration from groundwater with the condition that groundwater evaporation is negligible.

RS methods are used to expand from measurements of ET at discrete locations to the large scale that is required by resource managers. In two studies (Nagler et al., 2005a, b), MODIS EVI and maximum daily air temperatures (from MODIS land surface temperature LST) were used to derive an empirical estimate of riparian ET for the San Pedro River and middle Rio Grande of the USA (Nagler et al., 2005a, b). Their equations for daily ET were

$$
\begin{aligned}
\mathrm{ET} & =a\left(1-e^{-b \mathrm{EVI}^{*}}\right)\left(c /\left[1+e^{-\left\{T_{\mathrm{a}} d / e\right\}}\right]\right) \\
& +f(\text { middle Rio Grande }) \text { and } \\
\mathrm{ET} & =a\left(1-e^{-b \mathrm{EVI}^{*}}\right)(\mathrm{LST}-c)+d \text { (both rivers) }
\end{aligned}
$$

where $a, b, c, d, e$ and $f$ are regression constants derived by regression analysis, $T_{\mathrm{a}}$ is air temperature derived from MODIS LST retrievals, and EVI was normalised to obtain EVI* $^{*}$. Strong correlations between EVI*, $T_{\mathrm{a}}$ and ET were observed and used to provide scaled estimates for larger areas of vegetation. Despite this being an empirically derived equation from a single study, the form of the equation appears to be relatively robust across catchments (Nagler et al., 2005b). Similarly, Scott et al. (2008) and Nagler et al. (2009) applied these equations (Nagler et al., 2005a, b) in which they used MODIS-derived nocturnal surface temperature and daily maximal air temperature, respectively. In the regression between ET derived from RS and EC methods, the coefficient of determination $\left(R^{2}\right)$ was larger than 0.93 during all three years of study and across three vegetation types (grassland, shrubland and woodland), thereby indicating the broad applicability of this method. Thus, this method has the ability to (a) scale from point measurements using individual EC towers to much larger areas; and (b) estimate the difference between annual rainfall and ET and, where ET $>$ rainfall, estimate vegetation groundwater use.

\subsection{Gravity Recovery and Climate Experiment (GRACE) for detecting changes in total terrestrial water storage}

In addition to remote sensing measures of ET anomalies or NDVI green islands, there are also new satellite sensors and techniques that provide estimates of groundwater fluctuations and soil moisture storage changes that are of value to 
the study of GDEs (Brunner et al., 2007). The twin satellites known as the Gravity Recovery and Climate Experiment (GRACE) were launched in 2002 for the purpose of making detailed measurements of Earth's gravity field (Tapley et al., 2004). Although Earth's gravity variations tend to be relatively constant over long time intervals, more dynamic, time-variable gravity fields can be detected and these have been related to land surface moisture, groundwater fluctuations, sea ice, sea level rise, and deep ocean currents. GRACE's ability to monitor changes in such "unseen water reserves" from space are a significant new addition to hydrological studies that can substantially improve our knowledge of below- and above-ground water resources and associated changes to vegetation functioning and GDEs. However, GRACE is not able to estimate rates of actual groundwater use by GDEs.

Technically, the GRACE satellites detect changes in the Earth's gravity field by monitoring the changes in distance between the two spacecraft as they orbit the Earth. The relative distance will change in response to variations in the Earth's mass, including changes in mass of both above- and below-ground water reservoirs (groundwater, soil moisture, snow, ice, and surface waters). The GRACE satellite data directly measure changes in total water storage (TWS) and not changes in the individual hydrologic components (e.g. surface water, soil moisture, and groundwater). Groundwater storage changes from GRACE are thus inferred by isolating and removing the contributions of all other TWS components, using either independent hydrologic data sets and/or land surface models.

In most cases, soil moisture becomes the sole component that must be removed from the gravity data to estimate groundwater changes, since variability of snow and surface water is relatively insignificant to total water storage variability. By subtracting the soil moisture contribution, the remaining time-variable change in GRACE's measure of total water storage will be due to changes in groundwater. Thus,

$\Delta \mathrm{TWS}=\Delta \mathrm{SW}+\Delta \mathrm{SM}+\Delta \mathrm{GW}$,

where $\Delta \mathrm{TWS}, \Delta \mathrm{SW}, \Delta \mathrm{SM}$ and $\Delta \mathrm{GW}$ are changes in total water store, surface water, soil moisture, and groundwater respectively.

Many studies have compared changes in groundwater storage obtained from GRACE data with in situ data for validating the accuracy of GRACE data at either regional or continental scales (Henry et al., 2011; Leblanc et al., 2009; Rodell et al., 2009, 2007; Scanlon et al., 2012a, b; Syed et al., 2009).

GRACE is not a way to measure exact water storage amounts from space and cannot be used to measure how much water is stored in a river basin at a particular instant in time. Instead, gravity information is used to assess relative changes in water storage over large areas at monthly, seasonal or annual time steps. Seasonal changes in water storage may be the easiest to detect using the GRACE technique because such changes tend to be large.
In general, GRACE data are more accurate for large areas over long time intervals. For example, GRACE can detect seasonal and annual changes in water storage over large areas and can detect month-to-month changes over entire river basins (of the order of millions of square kilometres). Presently, GRACE can confidently detect water storage changes in areas larger than $200000 \mathrm{~km}^{2}$.

Rodell and Famiglietti (2001) showed that GRACE data can estimate annual groundwater change over the High Plains, USA, within about $8.7 \mathrm{~mm}$ of their actual value. This level of accuracy may not always be an improvement for well-sampled and instrumented aquifers, but for most places in the world, estimates of water levels within a centimetre or less are extremely valuable and will help reveal groundwater depletion in areas of the world where such measurements are not systematically recorded.

Despite these coarse scales, such information can be extremely useful for water resources managers, especially as GRACE data continue to be refined to provide improved estimates of groundwater fluctuations and depletion. Regional monitoring of groundwater levels is limited by the lack of ground-based measurements and the lack of a sufficiently extensive network of monitoring wells. Thereby, the GRACE technique offers an objective, unbiased method for monitoring water storage changes at large scales.

Although many advances in TWS monitoring have been made using GRACE data, the practical application of GRACE data for local water resources management has been limited by the low spatial $\left(>150000 \mathrm{~km}^{2}\right)$ and temporal ( $>10$ days) resolution of GRACE measurements and by difficulties in disaggregating the various TWS components (Rodell et al., 2007). There is a trade-off between coarse spatial resolution and accuracy, and it remains to be determined whether better spatial resolutions can be achieved without degrading or increasing the uncertainties. However, Houborg et al. (2012) show the potential value of GRACE data to significantly improve drought prediction capacity through assimilation of these data into the Catchment Land Surface Model using ensemble Kalman smoother and forcing data from North American and Global Land Data Assimilation Systems Phase 2 (NLDAS-2). Similarly, Sun et al. (2013) imposed GRACE observations as constraints when recalibrating a regional-scale groundwater model, further highlighting the value of GRACE data to the study of groundwater and GDEs.

\subsubsection{Downscaling of GRACE}

To fully realize the potential of GRACE data for hydrological applications, downscaling both in space and time is required. This will enable better predictions of changes in groundwater level (Houborg et al., 2012). Sun et al. (2013) explored various downscaling techniques for GRACE data for useful predictions of changes in water level. They developed artificial neural network (ANN) model schemes to predict 

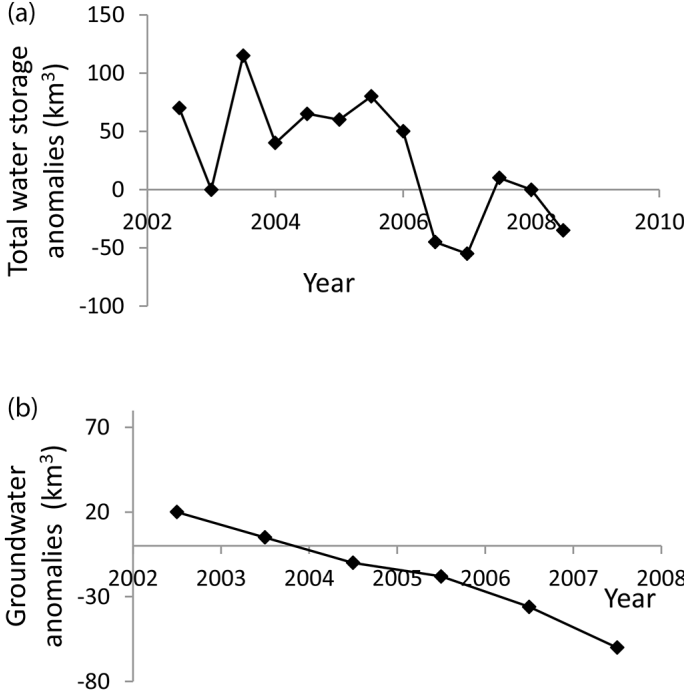

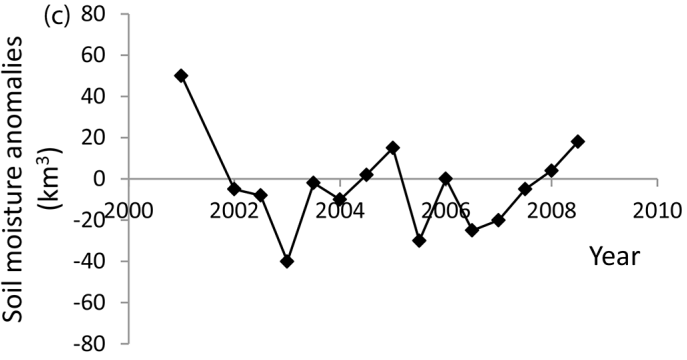

(d)

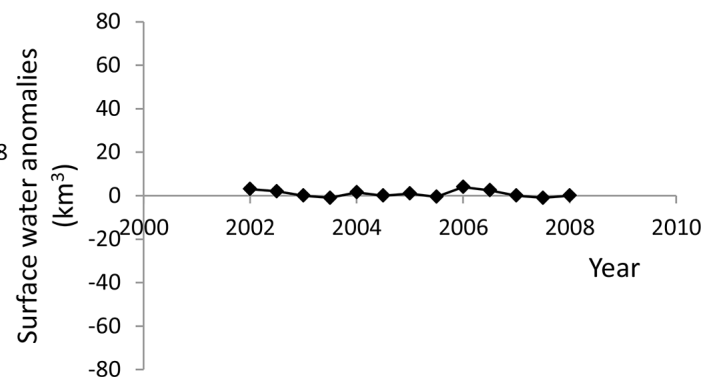

Figure 2. Change in (a) total water storage anomalies; (b) groundwater anomalies; (c) soil moisture storage anomalies; and (d) surface water anomalies relative to the mean of the Murray-Darling Basin during the multiyear drought. Redrawn from Leblanc et al. (2009).

such changes directly by using a gridded GRACE product and other publicly available hydrometeorological data sets. Their statistical downscaling approach can be readily integrated into local water resources planning activities, especially in the absence of continuous in situ groundwater observations. They noted that downscaled GRACE data could potentially fill the gap created by the declining coverage of in situ groundwater monitoring networks and "index" wells used to gauge the wellbeing of aquifers.

\subsubsection{Groundwater depletion studies and GRACE}

GRACE satellite data have been used to estimate groundwater depletion associated with severe droughts in Europe, the US, China, and India (Leblanc et al., 2009; Rodell et al., 2009). Groundwater pumping of aquifers often increases during severe droughts for urban, agriculture, livestock, and industry needs. This results in the decline of groundwater levels and the decrease in groundwater discharge to springs, surface water bodies and riparian zones (Peters et al., 2003). Leblanc et al. (2009) attempted to attribute groundwater loss during the recent drought in the Murray-Darling Basin in Australia to groundwater pumping. However, they found that the pumping rate represented only less than $10 \%$ of the decline rate in groundwater storage as observed by GRACE from 2003 to 2008 (Fig. 2). They concluded that the observed decline can mostly be explained by reductions of groundwater recharge and the vast amount of groundwater transpired during the drought by the widespread presence of deep rooted trees (GDEs) as well as capillary rise from the saturated to the unsaturated zone.

\subsection{Remote sensing limitations and challenges in studies of GDEs}

Remote sensing applications in studies of GDEs vary greatly, from basic detection, mapping, and monitoring of GDEs to more complex and quantitative measurements of ET, functioning, and energy and water balance. In most cases, mapping of GDE locations at appropriate management scales is prerequisite to more detailed studies, such as groundwater assessments that may require accurate estimates of ET (Gou et al., 2015).

Regardless of the application, there will be certain limitations in the use of remote sensing that need to be considered. Other geospatial data sources will often need to be integrated to make the best use of remote sensing, including climate, soils, landscape morphology, and ecologic data layers that will enable potential areas for GDEs to be delineated (Bertand et al., 2012). Multiple sensors and image data sets are best suited for studies of GDEs because of the inherent spectral-spatial-temporal limitations of single sensor systems. For example, the use of fine spatial resolution Landsat $(30 \mathrm{~m})$ and high temporal frequency MODIS data (1-2 day) allows us to identify potential GDE vegetation patches (Landsat) and track changes in their seasonal and inter-annual dynamics (MODIS spectral vegetation indices, VIs). Thus, vegetated areas that maintain high VI "greenness" values during extended dry periods can be flagged as "high GDE potential", under the premise that GDEs exhibit low seasonality in greenness and ET between dry and wet seasons and low inter-annual variability across years. 
However, many ecosystems may contain trees and shrubs that are non-GDE yet also exhibit weak seasonality and interannual variation due to their evergreen phenologies. In these mixed tree-grass landscapes, seasonal variability follows the very dynamic herbaceous grass layer that is strongly coupled to rainfall rather than groundwater availability. The stronger seasonality present in the grass layer can readily mask GDE signals from the tree layer and confuse GDE detection. This "mixed-pixel" problem restricts many remote sensing applications, particularly when the matrix background of an area with GDEs has insufficient thermal or greenness contrast to enable GDE detection. The detection of "cool" thermal patches (transpiring GDE trees) from relatively warmer backgrounds (soil) will be a function of the size and magnitude of the cold patch relative to the pixel area. The "greener" and "cooler" signals from a groundwater-dependent tree may be averaged out by the non-GDE plants present in the same pixel and a stressed GDE tree can gradually fade into the warmer soil background matrix. Spatial heterogeneity may overwhelm detection. Finer resolution imagery will improve detection capabilities, but temporal information is then made poorer, due to inherent sensor resolution trade-offs.

It should be noted that although remote sensing is a useful diagnostic tool and proxy for the detection and sensing of GDEs, most detection and mapping is done by inference and careful user interpretation. Remote sensing often cannot directly ascertain causes and mechanisms of GDEs, and much remains to be done to assess GDE influences on the water balance, their sensitivity to changing water availability, and responses to stress conditions. Future sensor systems planned for launch in the next few years include followon GRACE twin satellite missions with improved sensing capabilities allowing more detailed analyses of groundwater, soil moisture, and surface water distributions and trends. The soil moisture active passive (SMAP) mission, launched in 2014, provides improved soil moisture retrievals which will improve upon the detection and differentiation of soilmoisture-induced vegetation dynamics from those associated with groundwater use.

\section{Hydrological modelling of water use by GDEs}

\subsection{Conceptual water balance approaches}

\section{A spreadsheet tool}

O'Grady and co-workers have developed a simple but useful first-order approximation to estimate groundwater use of vegetation in an Excel spreadsheet tool (Leaney et al., 2011; http://www.csiro.au/products/ recharge-discharge-estimation-suite). This toolbox includes three methods to estimate rates of groundwater discharge by vegetation:

1. Groundwater Risk Model,

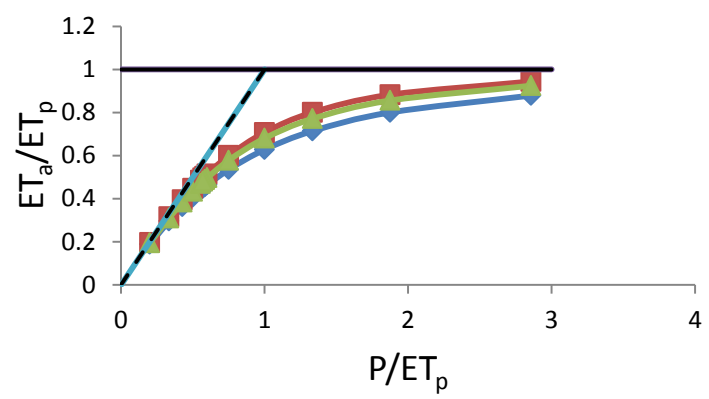

Figure 3. A representation of the Budyko formulation using the Choudhury-Yang formulation with three different values of $n$ (from 1.5 to 2.0). Redrawn from Leaney et al. (2011).

\section{Ecological Optimality Model, and}

3. Groundwater Discharge Salinity Model (not described here).

The groundwater risk model uses historical monthly rainfall and evaporation data for a site to produce a water balance. Soil texture is used to estimate soil moisture characteristics in each layer of the model, and groundwater uptake by vegetation is assumed to occur when ET exceeds rainfall, when also accounting for soil water storage for each month. ET is estimated from total evaporation using the Budyko framework (Budyko, 1974; Donohue et al., 2007; Yang et al., 2008; Roderick and Farquhar, 2009). The risk model in Leaney et al. (2011) uses the Choudhury-Yang formulation of the Budyko equation:

$\mathrm{ET}_{\mathrm{a}}=\left(P \mathrm{ET}_{\mathrm{p}}\right) /\left(P^{n}+\left[\mathrm{ET}_{\mathrm{p}}\right]^{n}\right)^{1 / n}$,

where $P$ is rainfall and $n$ is a fitting parameter that determines the shape of the curve. Determining the value of $n$ is difficult, but a close approximation can be derived from the climate wetness index $\left(\mathrm{CWI}=P / \mathrm{ET}_{\mathrm{p}}\right)$. When $\mathrm{CWI}>0.3$, $n$ is approximately equal to CWI and when CWI $<0.3, n$ is approximately 1.8 (Leaney et al., 2011). The influence of variation in $n$ and the Budyko formulation is shown in Fig. 3 .

The model is run using historical monthly rainfall and estimated ET. Pan evaporation rates can be used instead of $\mathrm{ET}_{\mathrm{p}}$, in which case $\mathrm{ET}_{\mathrm{p}}=0.75 E_{\mathrm{pan}}$. Modest agreement between modelled and observed rates of groundwater discharge was found in two Australian studies where ET exceeded rainfall in the Wattle Range by 2 to $440 \mathrm{~mm} \mathrm{yr}^{-1}$ (Benyon and Doody, 2004), although the range of estimated groundwater discharge rates was large: 107 to $671 \mathrm{~mm} \mathrm{yr}^{-1}$ (Benyon and Doody, 2004) and 380 to $730 \mathrm{~mm} \mathrm{yr}^{-1}$ (Benyon et al., 2006).

As an alternative method to the risk assessment just described, Leaney et al. (2011) applied Eagleson's theory of ecological optimality (Eagleson, 1978). This proposes that the LAI of a site is maximised according to long-term rainfall and soil water holding capacity such that productivity is maximised whilst minimising the development of water 
stress. In this hypothesis, native vegetation is assumed to be at equilibrium with the local hydrological regime (Nemani and Running, 1989). Ellis and Hatton (2008) have shown that the LAI of a site is proportional to a climate wetness index $\left(\mathrm{CWI}=P / \mathrm{ET}_{\mathrm{p}}\right)$, whilst Eamus et al. (2001) used the Baldocchi-Meyers index (foliar $[\mathrm{N}] \times P / E_{\mathrm{eq}}$, where foliar $[\mathrm{N}]$ is the concentration of nitrogen in leaves and $E_{\text {eq }}$ is equilibrium evapotranspiration) and found a strong $\left(R^{2}=0.95\right.$ for 16 sites globally) curvilinear relationship with LAI, supporting the essentials of Eagleson's optimality theory. Similarly, Zeppel (2013) examined multiple species across sites in Australia and found strong convergence in daily rates of tree water use and leaf area across five evergreen sclerophyllous genera. In the Eagleson optimality method of Leaney et al. (2011), the relationship between LAI and the CWI of Ellis and Hatton (2008) is used:

$\mathrm{LAI}=(3.31 \times \mathrm{CWI})-0.04$

In GDEs, groundwater discharge combines with precipitation to supply ET (O'Grady et al., 2011); thus,

$$
\mathrm{CWI}_{\mathrm{g}}=(P+\mathrm{GW}) / \mathrm{ET}_{\mathrm{p}},
$$

where $\mathrm{CWI}_{\mathrm{g}}$ is the climate wetness index that includes the groundwater component (GW). Likewise, the Budyko curve can be modified to include the contribution of groundwater discharge to ET:

$$
\mathrm{ET} / \mathrm{ET}_{\mathrm{p}}=1+\left(P / \mathrm{ET}_{\mathrm{p}}\right)-\left(1+\left[P / \mathrm{ET}_{\mathrm{p}}\right]^{w}\right)^{1 / w}
$$

(Zhang et al., 2004) and

$$
\begin{aligned}
\left(\mathrm{ET} / \mathrm{ET}_{\mathrm{p}}\right)_{\mathrm{g}} & =1+\left([P+\mathrm{GW}] / \mathrm{ET}_{\mathrm{p}}\right) \\
& -\left(1+\left[\{P+\mathrm{GW}\} / \mathrm{ET}_{\mathrm{p}}\right]^{w}\right)^{1 / w} \\
& \left(\mathrm{O}^{\prime}\right. \text { Grady et al., 2011). }
\end{aligned}
$$

Within zones of the same CWI, sites with access to shallow groundwater maintain a larger LAI than sites without access to groundwater (O'Grady et al., 2011). To determine GW, the pairs of equations $\left(\mathrm{CWI}, \mathrm{CWI}_{\mathrm{g}}\right.$; ET/ET $\mathrm{p}$, $\left.\left[\mathrm{ET}_{\mathrm{E}} / \mathrm{ET}_{\mathrm{p}}\right]_{\mathrm{g}}\right)$ were optimised by obtaining the difference in rainfall required to attain a given LAI with a known CWI value (O'Grady et al., 2011).

\subsection{Groundwater flow and variable saturation models: MODFLOW and HYDRUS}

Two models, MODFLOW and HYDRUS, are commonly used to investigate the hydrologic state of the coupled surface water-groundwater-soil-vegetation system (McDonald and Harbaugh, 1988; Doble et al., 2006; Shah et al., 2007; Lowry and Loheide, 2010; Loheide and Booth, 2011; Ajami et al., 2012). HYDRUS applies Richard's equation to simulate water, heat and solute movements in soil, whereas MODFLOW is a fully distributed and coupled hydrologic model of groundwater flow (Orellana et al., 2012). Hydrologic models that apply Richard's equation in a soil medium of variable saturation are important for evaluating the mechanisms that generate groundwater hydrographs and flow. MODFLOW can also perform spatial scaling of ET as a function of depthto-groundwater, although the form of ET depends upon parameterisation of the model. Often, $\mathrm{ET}$ is determined as $\mathrm{ET}_{\mathrm{p}}$ or $\mathrm{ET}_{0}$, but measurements of $\mathrm{ET}_{\mathrm{a}}$ from eddy covariance can also be used. In one example, Wilcox et al. (2007) estimated ET from Cleverly et al. (2002) to evaluate the interaction between riparian ET and surface water-groundwater interactions.

Variable saturation models have improved our understanding of the interactions between groundwater and soil moisture in the vadose zone. Root water uptake (RWU) creates soil moisture deficits in the vadose zone and the capillary fringe, thereby causing vadose zone water content to fluctuate with depth-to-groundwater (Nachabe et al., 2005; Shah et al., 2007; Logsdon et al., 2010). Using HYDRUS 1-D, Lowry and Loheide (2010) integrated ET $_{\mathrm{g}}$ and RWU from the vadose zone by estimating the groundwater subsidy as the difference between RWU from the shallow groundwater and RWU from free drainage. Further complicating the relationship between groundwater and soil moisture, hydraulic redistribution of moisture from deep in the soil column to the surface (i.e. hydraulic lift) can reduce the amplitude of fluctuations in depth-to-groundwater, increase the amount of $\mathrm{ET}_{\mathrm{g}}$ that is lost to groundwater evaporation, and decrease the nocturnal recovery in depth-to-groundwater (Orellana et al., 2012).

One of the goals of ecohydrological modelling in GDEs is the prediction of vegetation state based upon groundwater regime (Loheide and Booth, 2011). Likewise, the principle drivers of water use by vegetation in GDEs were aquifer attributes ( $S_{\mathrm{y}}$, regional groundwater flow), meteorology (solar radiation, vapour pressure deficit), environmental stress, and vegetation attributes (LAI, species composition) (Cleverly et al., 1997; Perkins and Sophocleous, 1999; Dahm et al., 2002; Cleverly et al., 2006; Butler et al., 2007; Lautz, 2008; Abudu et al., 2010). In general, these controls are observed in the wider literature on the controls of vegetation water use (Eamus et al., 2006b; Whitley et al., 2009). As the meteorological, environmental and vegetation effects on ET have been thoroughly described, we will focus on the regional aquifer effects on $\mathrm{ET}_{\mathrm{g}}$ here.

One geomorphologic attribute of the aquifer that controls the flow of groundwater and thereby affects the distribution of groundwater-dependent vegetation depends upon whether the aquifer is gaining (i.e. water flows into the aquifer from its surroundings) or losing (i.e. an area where groundwater is lost to adjacent unsaturated soils) (Cleverly, 2013). A larger $\mathrm{ET}_{\mathrm{g}}$ can lead to contrasting effects on seepage from streams to aquifers, depending upon whether along a losing or gaining reach (Ajami et al., 2011). Similarly, fluctuations in depth-to-groundwater can differ between gaining 
and losing reaches, of which the occurrence of the latter is where groundwater inflow might be insufficient to support large recovery rates in depth-to-groundwater (Schilling and Zhang, 2012). The relationships between plant water use, aquifer dynamics, and seasonality (e.g. Logsdon et al., 2010; Ajami et al., 2011) are influenced by the rooting patterns and groundwater depth-ET $\mathrm{g}_{\mathrm{g}}$ relationships of the specific plant functional types that inhabit the GDE (Baird and Maddock, 2005).

\section{Field-based measurements of water use by GDEs}

\subsection{Sub-daily fluctuation in groundwater depth}

An idealised representation of the White method in a shallow unconfined aquifer is shown in Fig. 4.

In Fig. 4 the oscillating curve represents the cycle of groundwater drawdown arising from evapotranspiration (ET) during the day followed by a "rebound" of the water table when ET returns to zero at night. The dashed straight line (with slope $=r$ ) provides an estimate of the recovery rate, which is how fast the water table rises in the absence of groundwater use (Butler et al., 2007). After accounting for recovery, the daily drawdown of the water table is scaled by the effective specific yield $\left(S_{\mathrm{y}}\right)$, or the volume of water (per unit surface area of an unconfined aquifer) released from the soil pores with a given change in depth-to-groundwater (White, 1932):

$\mathrm{ET}_{\mathrm{g}}=S_{\mathrm{y}}(24 r+s)$

where $s$ is the change in aquifer storage and is determined from the $24 \mathrm{~h}$ change in depth-to-groundwater. This approach has been successfully applied in the Okavango Delta in Botswana (Bauer et al., 2004), an upland grassland catchment in central Argentina (Engel et al., 2005), an oak/grassland site on the Great Hungarian Plain of eastern Hungary (Nosetto et al., 2007), the Sopron Hills of western Hungary (Gribovszki et al., 2008), the Gobi desert of northwestern China (Wang et al., 2014), and various sites in the USA (Butler et al., 2007; Lautz et al., 2008; Martinet et al., 2009).

The White method tends to over-estimate $\mathrm{ET}_{\mathrm{g}}$ (Loheide et al., 2005; Martinet et al., 2009). A major source of error is estimation of $S_{\mathrm{y}}$, to which this method is very sensitive (Loheide et al., 2005; Gribovszki et al., 2008; Lautz, 2008; Logsdon et al., 2010; Miller et al., 2010). Furthermore, representative measurements of the readily available $S_{\mathrm{y}}$ are difficult to make and are complicated by capillary flux, trapped air, hysteresis, and departure of the soil-water ecosystem from an equilibrium (Logsdon et al., 2010). The value of $S_{\mathrm{y}}$ is dependent upon soil texture (Loheide et al., 2005); thus, Martinet et al. (2009) applied a value of $S_{\mathrm{y}}$ that varied with the soil texture in contact with the capillary fringe of the water table. With a measure of $\mathrm{ET}_{\mathrm{g}}$ (e.g. from eddy covariance), the

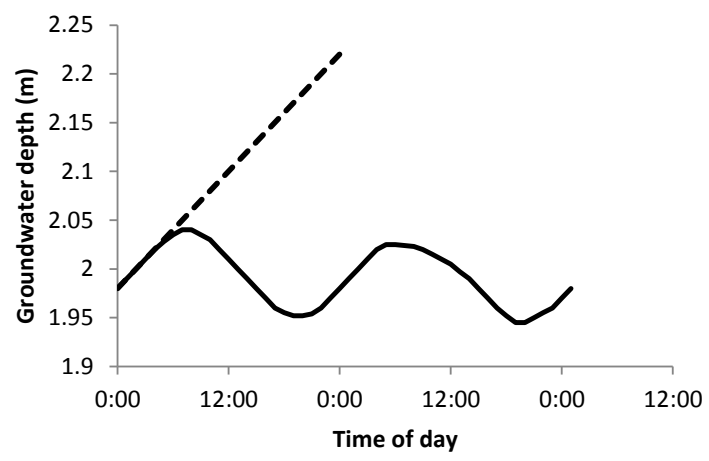

Figure 4. An idealised representation of changes in depth-togroundwater over a $48 \mathrm{~h}$ period. The water table declines (depth increases) during the day because of transpiration by vegetation but increases (depth decreases) at night when transpiration tends to zero and recharge exceeds loss. The dashed line represents the trajectory of overnight recharge in the absence of transpiration on the following day. See text for further discussion of this.

White equation can be inverted to investigate the variation in $S_{\mathrm{y}}$ (Miller et al., 2010). Using an inversion of the White method, estimates of $S_{\mathrm{y}}$ account for spatial heterogeneity in soil texture and scaling effects on $S_{\mathrm{y}}$, but further studies are required before comprehensive predictions of $S_{\mathrm{y}}$ can be obtained without independent measurements of $\mathrm{ET}_{\mathrm{g}}$. Alternatively, Nachabe et al. (2005) used a more direct estimate of $S_{\mathrm{y}}$ in the soil column by combining measured fluctuations of depth-to-groundwater and soil moisture across the vadose (i.e. unsaturated) zone. In either case, additional instrumentation to measure $\mathrm{ET}_{\mathrm{g}}$ or soil moisture profiles improved the estimation of $S_{\mathrm{y}}$.

Several modifications to the White method were evaluated in a study by Fahle and Dietrich (2014), in which they compared errors in estimation of $S_{\mathrm{y}}$, recovery and $\mathrm{ET}_{\mathrm{g}}$. No model outperformed the others in each of these error benchmarks, thus illustrating that errors in the estimation of $S_{\mathrm{y}}$ are compensated by errors in the estimation of recovery (Fahle and Dietrich, 2014). The methods that provided the best estimates for recovery of the groundwater used approaches to estimate sub-daily rates of $\mathrm{ET}_{\mathrm{g}}$ and recovery (Gribovszki et al., 2008; Loheide, 2008). In both methods, recovery was estimated from the previous and following nights, although application to other methods might require site-specific parameterisation of the time period that is most representative for their study conditions (e.g. 18:00-06:00; Fahle and Dietrich, 2014). In the method of Gribovszki et al. (2008), recovery was estimated from the time rate of change in depth-to-groundwater, and this important upgrade reduced the error of recovery estimates (Gribovszki et al., 2010; Fahle and Dietrich, 2014).

Groundwater hydrographs include the impact of regional fluctuations in the aquifer that are not associated with local changes arising from ET of vegetation (Engel et al., 2005). A regional effect that can cause problems with the White method occurs when tides from nearby water bodies gener- 
ate two daily peaks in the groundwater hydrograph (Miller et al., 2010), thereby requiring measurements of the water body that is causing the effect. After accounting for the regional hydrograph, soil moisture content in the vadose zone can still affect the correlation between sap flow measurements of $\mathrm{ET}_{\mathrm{g}}$ and groundwater fluctuations (Engel et al., 2005). This was consistent with the modelling results of Loheide et al. (2005), who found that daily fluctuations were dampened by root water uptake from the vadose zone alone. Spectral methods (e.g. windowed Fourier decomposition) are effective at identifying break points in the daily signal like those associated with regional groundwater and soil moisture effects, although variations in $\mathrm{ET}_{\mathrm{g}}$ can result in loss of amplitude, consequently rendering spectral analysis unsuitable for quantitative analysis without an adequate scaling factor (Schilling and Zhang, 2012; Soylu et al., 2012).

\subsection{Using stable isotopes to estimate rates of groundwater use}

Estimates of the proportion of total vegetation water use derived from groundwater can be determined from stable isotope analyses (Querejeta et al., 2007; Maguas et al., 2011; Feikema et al., 2010; Kray et al., 2012; McLendon et al., 2008). Two types of information are required to quantitatively partition $\mathrm{ET}_{\mathrm{g}}$ from ET. The first is an independent estimate of $\mathrm{ET}_{0}$ or $\mathrm{ET}_{\mathrm{a}}$ as derived from eddy covariance (Kelliher et al., 1992; Baldocchi and Vogel, 1996; Baldocchi and Ryu, 2011), sap flow (Cook and O'Grady, 2006; O'Grady et al., 2006a, b; Zeppel, 2013) or RS techniques (Nagler et al., 2009, 2013). The second is the stable isotope composition of water in soil, groundwater and xylem. Upon determination of the proportion of ET that is due to $\mathrm{ET}_{\mathrm{g}}$ (Sect. 3.2), the amount of $\mathrm{ET}_{\mathrm{g}}$, for example in $\mathrm{mm} \mathrm{day}^{-1}$, is the product of that proportion and ET.

Three generalities can be identified in the results of stable isotope studies of GDEs. First, multi-species comparisons at a common site generally confirm niche separation (spatially or temporally) in patterns of water uptake, thereby minimising competition for water (Lamontagne et al., 2005; Querejeta et al., 2007; Kray et al., 2012). Second, increased depth-to-groundwater results in a declining proportion of groundwater use (O'Grady et al., 2006), although this can vary amongst different vegetation communities (McLendon et al., 2008). Finally, as time since last rain increases, the proportion of groundwater used by vegetation usually increases (McLendon et al., 2008), but not always (Kray et al., 2012). Consequently, seasonality of groundwater use may occur when rainfall is highly seasonal and groundwater availability is maintained throughout the dry season (O'Grady et al., 2006).

Stable isotope composition varies with depth (Table 1; Querejeta et al., 2007). Consequently, taking an average value to represent the entire rooting depth can lead to errors. Whilst use of two independent isotopes allows the relative contribution of three sources to be determined, obtaining independence of both isotopes is very difficult. As an alternative, Cook and O'Grady (2006) developed a model that estimates the relative water uptake by vegetation from different soil depths. This model is based upon the following axioms: the rate of water uptake is determined by (a) the gradient in water potential between bulk soil and leaves; (b) root distribution through the soil profile; and (c) a lumped hydraulic conductance parameter. Soil isotopic composition as a function of depth and of xylem water is used to constrain root distributions within the model. This has the advantage over endmember analyses (an analytic tool to determine the relative contributions of soil water and groundwater to transpiration; Phillips and Gregg, 2003) because (i) it produces a quantitative estimation of the proportion of water extracted from multiple depths (including groundwater); (ii) it does not require distinct values of isotope composition for end-member analyses and therefore can deal with the more typical grading of isotope composition observed through the soil profile; and (iii) it is based on simple ecophysiological principles. Cook and O'Grady (2006) applied this model and demonstrated that two co-occurring species obtained 7-15\% of their transpirational water from the water table, a third species accessed $100 \%$ from the water table, and a fourth species derived $53-77 \%$ from groundwater.

\section{Functional responses of GDEs to changes in GW depth}

\section{Effects of groundwater on growth and dendrochronological traits}

A reduced growth rate in response to declining water availability is a universally observed plant response (Kelliher et al., 1980; Osmond et al., 1987; Oberhuber et al., 1998; Sarris et al., 2007). In most GDEs rainfall and groundwater provide important supplies of water, and the ratio of rainfallto-groundwater uptake varies spatially and temporally. Consequently, increases in groundwater depth may be expected a priori to have the potential to affect plant growth. Dendrochronology (the study of growth in tree rings) has a long history in ecological research spanning many decades (Drew and Downes, 2009; McCarroll and Loader, 2004). However, its application to the study of GDEs is much more recent (e.g. Giantomasi et al., 2012). Similarly, recording point dendrometers, which are sensitive stem gauges that monitor growth increment at hourly timescales, recently have been used for expanding applications. In this section we briefly review some of the insights gained form dendrochronology and dendrometry in the study of GDEs.

Tree rings represent the history of past growth events, which are often but not always annual (Prior et al., 2012). Quantification of growth rates from tree rings can be used to reconstruct fluctuations in the supply water from precip- 
itation and groundwater (Oberhuber et al., 1998; Bogino and Jobbagy, 2011; Perez-Valdivia and Sauchyn, 2011; Xiao et al., 2014). In mountainous regions where the regional water supply is derived from snowmelt, tree growth and groundwater depth are correlated with precipitation during the year prior to growth because much of the snow received in the winter melts in the year after it fell (Oberhuber et al., 1998; Perez-Valdivia and Sauchyn, 2011). Likewise, tree ring growth and groundwater fluctuations are correlated to the dominant climate driver in an area (e.g. the Pacific decadal oscillation and El Niño-Southern Oscillation in California, USA) (Hanson et al., 2006). In some circumstances, the effect of groundwater can be disentangled from climate through the use of spectral analysis (Bogino and Jobbagy, 2011), but in other cases depth-to-groundwater was not found to be a significant factor in explaining differences in either ring width of basal area increment (Stock et al., 2012).

The timing of groundwater dependence can influence the presence of a climate signal in tree rings: climate signals can be weaker during formation of late wood, when growth rates are small (Oberhuber et al., 1998), or during the dry season, when precipitation rates are negligible and growth is supported by groundwater (Drake and Franks, 2003). Thus, analysis of tree ring chronologies can provide an insight into the importance of access to groundwater for plant growth. Individual events can be identified in the tree ring growth record (Hultine et al., 2010), as can long-term trends in depth-togroundwater (Bogino and Jobbagy, 2011). In riparian cottonwood trees and willows, Hultine et al. (2010) identified rapid, large and reversible responses of tree ring width to draining and refilling of a reservoir (Fig. 5).

Longer-term trends in depth-to-groundwater have impacted dendrochronologies in both directions, toward lower growth rates with groundwater extraction (Lageard and Drew, 2008) and toward increasing growth rates with decreasing depth-to-groundwater, except in response to root anoxia arising from flooding (Bogino and Jobbagy, 2011). However, specific responses depend upon depth-togroundwater and individual differences amongst functional types; for example, riparian cottonwood trees ( $P$. fremontii) responded to rewetting with growth that was larger and faster than the response of co-occurring willow ( $S$. exigua), a smallstature, thicket-forming shrub that is restricted to streamside areas with very shallow groundwater (Scurlock, 1998; Rood et al., 2011). From an understanding of the relationships between tree growth and depth-to-groundwater, historical periods of sensitivity to hydrological drought (i.e. affecting groundwater levels) versus meteorological drought (i.e. below-average precipitation) can be identified (Potts and Williams, 2004; Adams and Kolb, 2005; Cocozza et al., 2011). Such insights have value in developing a long-term understanding of the relationships amongst GDEs, climate and groundwater depth.

Wood formed during drought is enriched in ${ }^{13} \mathrm{C}$, reflecting decreases in stomatal conductance relative to photosynthesis

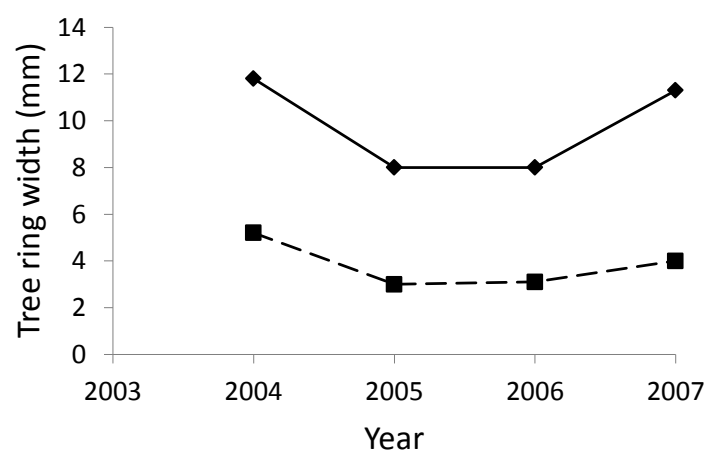

Figure 5. Change in tree ring width of cottonwood (solid line, diamonds) and willow (dashed line, squares) before (2004), during (2005-2006) and after draining the reservoir (early 2005) and refilling (mid 2006). Redrawn from Hultine et al. (2010).

and the consequential ratio of $\left[\mathrm{CO}_{2}\right]$ within and outside of the leaf $\left(C_{\mathrm{i}} / C_{\mathrm{a}}\right)$ (McCarroll and Loader, 2004; Cocozza et al., 2011; Horton et al., 2001; Maguas et al., 2011). Interpretation of $\delta^{13} \mathrm{C}$ in tree rings can be complicated by the effects of phloem loading (Gessler et al., 2009) and by photosynthetic re-fixation in the bark (Cernusak et al., 2001), although with independent confirmation, xylem $\delta^{13} \mathrm{C}$ can explain differences in groundwater use and water stress in groundwaterdependent trees. In one such comparison, $\delta^{13} \mathrm{C}$ was constant across xylem from Populus along a perennial stream (thereby implying access to groundwater), but changed with moisture conditions in an intermittent reach (Potts and Williams, 2004). Likewise, changes in ring width over time were reflected by $\delta^{13} \mathrm{C}$ from leaves (Hultine et al., 2010), such that less negative values of $\delta^{13} \mathrm{C}$ indicated increased water-use efficiency when the supply of water was reduced.

On small timescales (hourly to daily), incremental stem growth (and shrinkage) is measured using precision dendrometers that contain linear-variable-displacement transducers (Zweifel et al., 2005; Drew et al., 2008; Drew and Downes, 2009). Changes in maximum daily trunk shrinkage arising from reduced water availability occur earlier and stronger than changes in stomatal conductance, stem water potential or transpiration (Ortuno et al., 2006; Conejero et al., 2007, 2011; Galindo et al., 2013). Nonetheless, rates of sap flow declined with maximum daily stem shrinkage, both of which responded exponentially to changes in depth-to-groundwater (Ma et al., 2013). Similarly, February et al. (2007) and Drake et al. (2013) found that increased groundwater supply (actual or simulated) resulted in increased stem increment, sap flow and xylem water potential.

\section{Two case studies}

Two case studies are now presented, one from Australia and one from the USA. These case studies serve several purposes. 
First, they provide examples of the multiple approaches required in the study of GDEs (physiological, remote sensing, ecological). Second, they provide a valuable bridge between Sects. 2-6 (water use, remote sensing, modelling) and Sect. 8 (vegetation response trajectories to changes in groundwater depth). Finally, they integrate the results of many years of concentrated study into two diverse ecosystems.

\subsection{The Gnangara Mound}

The Gnangara Mound is a shallow unconfined aquifer of the Swan Coastal Plain in Western Australia. Increased depth-togroundwater has occurred over the past several decades as the result of long-term declines in annual rainfall, increased human abstraction and increased discharge arising from the development of a plantation industry in the region (Elmahdi and McFarlane, 2012). The impacts of groundwater abstraction on woodlands have been documented in this region (Groom et al., 2000; Canham et al., 2009, 2012; Stock et al., 2012). In 1985 large rates of summer abstraction in this Mediterranean climate were associated with increased and widespread mortality of native woodlands (up to $80 \%$ mortality close to abstraction bores; Mattiske and Associated, 1988).

To determine long-term floristic changes associated with groundwater abstraction, a series of transect studies were initiated in 1988. A $2.2 \mathrm{~m}$ increase in depth-to-groundwater coupled to higher-than-normal summer temperatures resulted in further adult mortality of overstorey species by as much as $80 \%$; additionally, $64 \%$ mortality was recorded in understory species 2 years after the start of groundwater abstraction (Groom et al., 2000). Increased rates of mortality were not observed at control sites that were not subject to groundwater pumping.

Large inter-specific differences in rates of mortality were observed in these Gnangara studies. Consequently, a further study examined the vulnerability of individual species to increased depth-to-groundwater (Froend and Drake, 2006; Canham et al., 2009). Using xylem embolism vulnerability curves as a measure of sensitivity to water stress, Froend and Drake (2006) compared three Banksia and one Melaleuca species. They found that xylem vulnerability reflected the broad ecohydrological distribution of species across a topographic gradient, and they identified a threshold leaf water potential below which increased mortality was likely. Similarly, Canham et al. (2009) examined Huber values (the ratio of sapwood to leaf area), leaf-specific hydraulic conductivity $\left(k_{1}\right)$ and xylem vulnerability of two obligate phreatophytes and two facultative phreatophytes. At sites where depth-togroundwater was shallow, there were no inter-specific differences in vulnerability to water stress. However, by comparing across a topographic gradient, Canham et al. (2009) showed that two facultative phreatophytes (but not the obligate phreatophytes) were more resistant to xylem embolism at the upper slope (larger depth-to-groundwater) than the lower slope.
It is not only above-ground tissues that adapt to changes in groundwater depth. Differences in root growth also respond to changes in depth-to-groundwater. Thus Canham et al. (2012) found that root growth varied with depth within the soil column: at the surface, root growth responded to seasonality and microclimate; at depth, root growth occurred all year and was dependent upon soil aeration (i.e. roots elongated rapidly following a declining water table during the summer and died back in the following winter as the groundwater rebounded). These results are consistent with the increases in ET following groundwater decline that were observed by Cleverly et al. (2006). The ability to rapidly increase root depth during the (dry) summer is a critical attribute of phreatophytes occupying sites with seasonally dynamic depth-to-groundwater.

The development of ecosystem response trajectories for the impact of groundwater abstraction is an important resource management imperative. Froend and Sommer (2010) examined a rare, 40-year vegetation survey data set from the Gnangara Mound. Whilst the long-term average (19762008) rainfall was $850 \mathrm{~mm}$, the annual average for the recent past was about $730 \mathrm{~mm}$ and depth-to-groundwater has increased by $1 \mathrm{~m}$ in the past 50 years. Depth-to-groundwater fluctuates about $0.5-3 \mathrm{~m}$ seasonally, and maximal depth occurs at the end of summer. Two transects were compared: a "control" where gradual increases in depth-to-groundwater $\left(9 \mathrm{~cm} \mathrm{yr}^{-1}\right)$ have occurred as a result of the decline in annual rainfall; and an "impacted" transect where large rates of increase in depth-to-groundwater have occurred $\left(50 \mathrm{~cm} \mathrm{yr}^{-1}\right)$. Principal component analyses were used to identify three vegetation communities: those associated with down-slope, mid-slope and upper-slope positions. Species having a high reliance on consistent water supplies (mesic species) were dominant at the down-slope site, while xeric species dominated the upper-slope sites.

On the control transect it was hypothesised that groundwater decline would result in a replacement of the mesic by the xeric species. However, this hypothesis was not supported. Indeed, most of the compositional and structural attributes of the three communities remained unchanged. The principle community-scale response was a change in the abundance of mesic and xeric species rather than complete replacement of one species for another. In contrast to the results of Shatfroth et al. (2000), mesic species at sites with shallow groundwater were not more sensitive to increases in depth-to-groundwater than xeric species. By contrast, changes in composition on the impacted transect were far more pronounced, and mass mortality was observed across all classes (mesic to xeric) species. This study emphasises the importance of the rate of change in depth-to-groundwater as a determinant of the response of species and communities. 


\subsection{Riparian forest vegetation in the south-western USA}

In the south-western USA, the majority of GDEs are riparian or littoral, where a shallow aquifer is formed by runoff from snowmelt in the mountainous headwaters. Much of the agriculture in the region is found along the rivers due to the large amount of surface water that flows past. The focus of irrigation to the riparian corridors has placed intense competition between water resources for people versus the environmental flows that are required to maintain shallow aquifers and associated GDEs. Of further risk to riparian GDEs and agriculture, groundwater extraction and land use change threaten riparian ecosystems (Scott et al., 1999; Nippert et al., 2010; Pert et al., 2010). Thus, many studies have been undertaken over several decades to investigate the water use of GDEs in south-western North America (van Hylckama, 1970; Gay and Fritschen, 1979; Sala et al., 1996; Devitt et al., 1998; Goodrich et al., 2000a; Cleverly et al., 2002; Scott et al., 2004; Nagler et al., 2005b).

Sunlight is plentiful in the south-western USA; thus, riparian GDEs are strong carbon sinks (Kochendorfer et al., 2011). However, seasonal variability in surface water discharge and aquifer recharge can create cycles of hypoxia and drought stress (Lowry et al., 2011), both of which act to reduce production (Shah and Dahm, 2008). Often existing between these two states of stress, riparian vegetation can transpire substantial amounts of water, reaching near the theoretical maximum $\left(\sim 12 \mathrm{~mm} \mathrm{day}^{-1}\right)$ (Cleverly, 2013). This general release from limitations due to energy, moisture and stress results in rates of latent heat flux that exceed precipitation (i.e. ET $/ P>1$ ) (Scott et al., 2000, 2006b; Cleverly et al., 2006) and net radiation (Devitt et al., 1998). Even when little or no groundwater use can be identified in the vegetation (e.g. in Sporobolis), ET losses from the riparian corridor can exceed precipitation inputs (Scott et al., 2000), implying that soil moisture in the vadose zone can be recharged by groundwater and that riparian GDEs need not use the groundwater directly.

In south-western North America, vegetation in riparian corridors and adjacent rangelands or shrublands is classified by reliance upon access to groundwater (i.e. obligate or facultative phreatophyte; Smith et al., 1998) or plant functional type (obligate wetland, shallow-rooted or deep-rooted riparian, transitional riparian, or upland; Pockman and Sperry, 2000; Baird and Maddock, 2005; Baird et al., 2005). The result of groundwater depletion has distinct effects on the vegetation in each functional type. Shallow-rooted, obligate phreatophytes (e.g. cottonwood, Populus spp.) can be very sensitive to groundwater decline, resulting in reductions of ET, productivity and canopy conductance as a consequence of increases in vapour pressure deficit that are correlated with depth-to-groundwater (Gazal et al., 2006; Kochendorfer et al., 2011). Branch sacrifice, partial crown dieback and mortality commonly occur in Populus following substantial groundwater drawdown (Mahoney and Rood, 1991; Kranjeec et al., 1998; Scott et al., 1999; Rood et al., 2000, 2003; Cooper et al., 2003). However, stomatal closure and crown dieback in Populus can prevent total hydraulic failure, and thereby minimise mortality rates, by maintaining favourable xylem water potentials within the remainder of the crown (Amlin and Rood, 2003).

Decreased baseflow and drawdown of groundwater levels has been associated with a shift in dominance to xerophytic species in the American Southwest at the expense of forbs and obligate phreatophytes (Stromberg et al., 1996, 2006, 2007, 2010). Xerophytes in the riparian corridors of the American Southwest include deep-rooted phreatophytes (e.g. Proposis, Tamarix) and upland species (e.g. Chrysothamnus), any of which may be opportunistic users of groundwater or groundwater-independent. Stress tolerance, opportunistic use of groundwater and use of multiple water sources (e.g. soil moisture) have contributed to the invasive success of Tamarix (Busch et al., 1992; Cleverly et al., 1997; Di Tomaso, 1998; Nippert et al., 2010). Consequently, Tamarix inhabit sites with variable depth-togroundwater (Lite and Stromberg, 2005), which results in an amount of ET that is equivalently variable in time and space (Cleverly et al., 2002; Cleverly, 2013).

The effective area of riparian vegetation has historically increased in the American Southwest due to expansion of deep-rooted phreatophytes like Tamarix and Prosopis (Hultine and Bush, 2011). The upland vegetation that previously occupied riverine upper terraces and grasslands supported small rates of ET (Shafroth et al., 2005; Hultine and Bush, 2011); thus, expansion of phreatophytes into these areas has resulted in an increase in ET losses (Scott et al., 2006b; Cleverly, 2013) and thereby has placed a potential strain on groundwater resources. In the case of expansion by Tamarix, groundwater extraction may result in enhancement of ET (Cleverly et al., 2006), contrasting with post-extraction reductions in ET by native, shallow-rooted phreatophytes such as Populus (Cooper et al., 2006; Gazal et al., 2006) and thus representing a shift in the ecohydrology of riparian corridors throughout the semi-arid regions of south-western North America.

\section{Integrating multiple-scale responses}

\subsection{Multiple traits across leaf, branch, whole-tree and stand}

The responses of vegetation to differences in depth-togroundwater have been examined extensively at leaf, tree, canopy and population scales. Rates of leaf-scale photosynthesis, stomatal conductance, whole plant hydraulic conductance, tree- and canopy-scale transpiration and plant density are known to decline in response to reduced supply of groundwater (Table 3). Similarly, increased Huber value, 
Table 3. A summary of some of the recent literature documenting the response of vegetation, across multiple scales, to reduced availability of groundwater.

\begin{tabular}{|c|c|c|}
\hline Process/trait & $\begin{array}{l}\text { Response to reduced availability of } \\
\text { groundwater and range of depths }\end{array}$ & References \\
\hline $\begin{array}{l}\text { Leaf-scale } \\
\text { photosynthesis }\end{array}$ & Decreased (zero to -9 m DGW); & Horton et al. (2001) \\
\hline $\begin{array}{l}\text { Stomatal } \\
\text { conductance }\end{array}$ & $\begin{array}{l}\text { Decrease (zero to }-9 \mathrm{~m} \text { DGW); } \\
\text { Decreased (zero to }>-1 \mathrm{~m} \text { DGW increased); } \\
\text { Stomatal resistance increased from } 38.8 \text { to } 112.5 \\
\text { (zero to }>-3 \mathrm{~m} \text { DGW) } \\
\text { Decreased ( }-7 \text { to }-23 \mathrm{~m} \text { DGW) } \\
\text { Decreased ( }-2 \text { to }-4 \mathrm{~m} \text { DGW) }\end{array}$ & $\begin{array}{l}\text { Horton et al. (2001) } \\
\text { Cooper et al. (2003) } \\
\text { Zunzunegui et al. (2000) } \\
\text { Gries et al. (2003) } \\
\text { Kochendorfer et al. } \\
(2011)\end{array}$ \\
\hline $\begin{array}{l}\text { Canopy } \\
\text { conductance }\end{array}$ & $\begin{array}{l}\text { Decreased ( }-1.5 \text { to }>-5 \mathrm{~m} \mathrm{DGW}) \\
\text { Decreased ( }-2 \text { to }-4 \mathrm{~m} \mathrm{DGW})\end{array}$ & $\begin{array}{l}\text { Carter and White (2009) } \\
\text { Kochendorfer et al. } \\
\text { (2011) }\end{array}$ \\
\hline $\begin{array}{l}\text { Leaf and stem } \\
\text { water } \\
\text { potential }\end{array}$ & $\begin{array}{l}\Psi_{\mathrm{pd}} \text { decrease from }-0.5 \text { to }-1.7 \mathrm{MPa} \text { (zero to }-9 \mathrm{~m} \text { ); } \\
\Psi_{\mathrm{pd}} \text { decreased from } 0.2-0.4 \text { to }-0.4 \text { to }-0.8 \mathrm{MPa} \\
\text { (zero to }>-1 \mathrm{~m} \text { DGW increased); } \\
\text { Decreased from }-0.79 \text { to }-2.55 \mathrm{MPa}(<-2 \text { to } \\
-20 \mathrm{~m} \text { DGW); } \\
\text { Decreased from }-1.85 \text { to }-3.99 \text { (zero to } \\
>-3 \mathrm{~m} \text { DGW) } \\
\Psi_{\text {midday decreased }(-7 \text { to }-23 \mathrm{~m} \mathrm{DGW} \text { ) }}\end{array}$ & $\begin{array}{l}\text { Horton et al. (2001) } \\
\text { Cooper et al. (2003) } \\
\text { Froend and Drake (2006) } \\
\text { Zunzunegui et al. (2000) } \\
\text { Gries et al. (2003) }\end{array}$ \\
\hline $\begin{array}{l}\text { Transpiration } \\
\text { Gazal et al. (2006) } \\
\text { Ford et al. (2008) } \\
\text { rate }\end{array}$ & $\begin{array}{l}\text { Et decreased ( }-2 \text { to }-4 \mathrm{~m} \text { DGW) } \\
E \text { decreased from } 966 \text { to } 484 \mathrm{~mm}(-1.1 \text { to } \\
-3.1 \mathrm{~m} \text { DGW) } \\
\text { Annual } E \text { decreased (zero to }-8 \mathrm{~m} \mathrm{DGW)}\end{array}$ & $\begin{array}{l}\text { Kochendorfer et al. } \\
\text { (2011) }\end{array}$ \\
\hline $\begin{array}{l}\text { Resistance to } \\
\text { xylem } \\
\text { embolism }\end{array}$ & $\begin{array}{l}\text { Increased ( }-1.5 \text { to }-30 \mathrm{~m} \mathrm{DGW}) \\
\mathrm{PLC}_{50} \text { decreased from }-1.07 \text { to }-3.24 \mathrm{MPa}(<-2 \text { to } \\
>-20 \mathrm{~m} \text { DGW) }\end{array}$ & $\begin{array}{l}\text { Canham et al. (2009) } \\
\text { Froend and Drake (2006) }\end{array}$ \\
\hline Growth rate & $\begin{array}{l}\text { Decreased (zero to }>-1 \mathrm{~m} \text { DGW increased); } \\
\text { Decreased ( }-7 \text { to }-23 \mathrm{~m} \text { DGW) }\end{array}$ & $\begin{array}{l}\text { Scott et al. (1999) } \\
\text { Gries et al. (2003) }\end{array}$ \\
\hline $\begin{array}{l}\text { Leaf area } \\
\text { index }\end{array}$ & $\begin{array}{l}\text { Decreased from } 3.5 \text { to } 1.0(-1.5 \text { to }>-5 \mathrm{~m} \mathrm{DGW}) \\
\text { Decreased } \\
\text { Decreased from } 2.5 \text { to } 0.66 \text { (zero to }>-3 \mathrm{~m} \mathrm{DGW}) \\
\text { Decreased from } 2.7 \text { to } 1.7(-1.1 \text { to }-3.1 \mathrm{~m} \mathrm{DGW})\end{array}$ & $\begin{array}{l}\text { Carter and White (2009) } \\
\text { O'Grady et al. (2011) } \\
\text { Zunzunegui et al. (2000) } \\
\text { Gazal et al. (2006) }\end{array}$ \\
\hline $\begin{array}{l}\text { Huber value } \\
\text { (SWA/LA) }\end{array}$ & $\begin{array}{l}\text { Increased from } 3.3 \text { to } 4.7(-1.1 \text { to }-3.1 \mathrm{~m} \text { DGW) } \\
\text { No change }(-1.5 \text { to }-30 \mathrm{~m} \text { DGW }) \\
\text { Increased from } 3.4 \text { to } 4.3 \times 10^{-4}(-1.5 \text { to } \\
>-5 \mathrm{~m} \text { DGW })\end{array}$ & $\begin{array}{l}\text { Gazal et al. (2006) } \\
\text { Canham et al. (2009) } \\
\text { Carter and White (2009) }\end{array}$ \\
\hline Plant density & $\begin{array}{l}\text { Vascular species number decreased; } \\
\text { Species composition changed ( }-0.9 \text { to } \\
-2.5 \mathrm{~m} \text { DGW); } \\
\text { plant cover type changed ( }-1.1 \text { to }-2.5 \mathrm{~m} \text { DGW); } \\
\text { vegetation cover and diversity decreased ( }-1 \text { to } \\
-110 \mathrm{~m} \text { DGW) }\end{array}$ & $\begin{array}{l}\text { Zinko et al. (2005) } \\
\text { Cooper et al. (2006) } \\
\text { Merritt and Bateman } \\
\text { (2012) } \\
\text { Lv et al. (2013) }\end{array}$ \\
\hline NDVI & $\begin{array}{l}\text { Decreased ( }-1 \text { to }-110 \mathrm{~m} \text { DGW); } \\
\text { Decreased (zero to }-1.5 \mathrm{~m} \text { DGW increased) } \\
\text { Decreased ( }-1.8 \text { to }-3.5 \mathrm{~m} \text { DGW) }\end{array}$ & $\begin{array}{l}\text { Lv et al. (2013) } \\
\text { Aguilar et al. (2012) } \\
\text { Wang et al. (2011) }\end{array}$ \\
\hline $\begin{array}{l}\text { Crown } \\
\text { dieback }\end{array}$ & $\begin{array}{l}\text { Increased between }<40 \text { to }>50 \% \text { (zero to }-9 \mathrm{~m}) \\
\text { Leaf loss } 34 \% \text { (zero to }>-1 \mathrm{~m} \text { DGW increased) }\end{array}$ & $\begin{array}{l}\text { Horton et al. (2001) } \\
\text { Cooper et al. (2003) }\end{array}$ \\
\hline Mortality & $\begin{array}{l}\text { Increased ( }>-2.2 \text { DGW increased) } \\
\text { Increased (zero to }>-1 \mathrm{~m} \text { DGW increased) } \\
\text { Increased ( }-0.4 \text { to }-5 \mathrm{~m} \text { DGW) }\end{array}$ & $\begin{array}{l}\text { Groom et al. (2000) } \\
\text { Scott et al. (1999) } \\
\text { González et al. (2012) }\end{array}$ \\
\hline
\end{tabular}


crown dieback and mortality in response to reduced supply of groundwater have been observed (Table 3). Consequently, response functions for individual traits are readily apparent; examples include changes with depth-to-groundwater in rates of photosynthesis (Horton et al., 2001), plant cover (Elmore et al., 2006), NDVI (Lv et al., 2012) and crown dieback (Horton et al., 2001). However, few studies have examined multiple traits across multiple scales and then provided an integrated "ecosystem-scale" response function to differences in groundwater availability. Integrated ecosystem-scale responses to changes in groundwater availability have been hypothesised to be linear (Fig. 6), curvi-linear or a step function with which minimal damage occurs until a threshold is reached (Leffler and Evans, 1999; Eamus et al., 2006).

Information on how vegetation adapts to differences in water supply is critical for predicting vegetation survival, growth and water use, which have important impacts on site hydrology (McDowell et al., 2008; Carter and White, 2009). The development of integrated response curves to reduced groundwater availability would significantly enhance our understanding of water requirements and lead to the identification of response thresholds. Such thresholds could be used to identify the limits of reduction in water-source availability, a useful parameter for characterising water requirements for resource and conservation management (Froend and Drake, 2006).

In a recent comprehensive, 3-year study, Zolfaghar (2014) examined leaf, branch, tree and stand-scale functional and structural attributes of woodlands across a gradient of depthto-groundwater ( 2.4 to $37.5 \mathrm{~m}$ ) in mesic Australia. She examined eighteen traits, including stand-scale basal area and tree height, leaf turgor loss point, sapwood hydraulic conductivity, sensitivity to xylem embolism and above ground net primary productivity. An increase in depth-to-groundwater across these sites was hypothesised to result in

1. reduced standing biomass;

2. adjustment of leaf-, tree- and plot-scale plant traits with associated repercussions for plant water relations;

3. increased drought tolerance; and

4. increased water-use efficiency.

Figure 7 provides a summary of the observed responses of each trait to increasing depth-to-groundwater. Refer to Table 4 for the abbreviations used in Fig. 7.

It is clear from Fig. 7 that increased depth-to-groundwater was associated with declines in basal area, tree height and LAI, and hence light interception, of native woodlands. As a consequence, above-ground net primary productivity was reduced as groundwater availability declined. Increased drought tolerance, as indicated by increased water-use efficiency, an increased Huber value and reduced water potential at turgor loss and solute potential at full turgor, supported

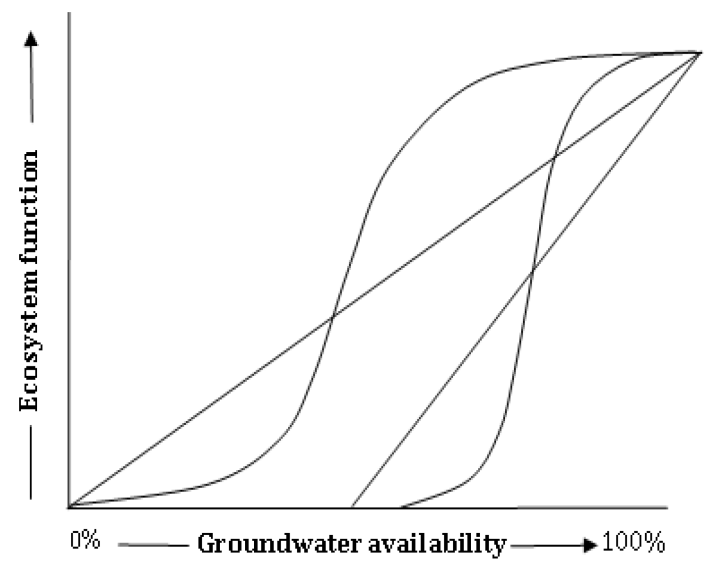

Figure 6. Hypothetical response functions for ecosystem function to differences in groundwater availability. From Eamus et al. (2006).

the principle over-arching hypothesis of increasing depth-togroundwater results in a suite of leaf-branch and tree-scale adaptations that increase tree tolerance to reduced water supply.

A key aspect of this research was to develop an ecosystem-scale response function for depth-to-groundwater. Zolfaghar (2014) normalised the responses (0 to 1 ) such that a response of 1 indicates no effect of differences in depthto-groundwater and 0.5 indicates a $50 \%$ decline/increase in the maximal/minimum value of a particular trait. The normalised response function is presented in Fig. 8. Despite the large number of traits and species across the seven sites, the standard error of the ecosystem-scale average for each data point was remarkably small, indicating significant convergence in normalised responses to differences in depth-togroundwater. Convergence of functional variations in traits across sites and species is increasingly observed with respect to rainfall or other climatic variables (Wright et al., 2004; Kattge et al., 2011). Indeed, identification of plant functional types (PFTs) is a practical means for models of land surfaceatmosphere interactions across biomes to integrate the physiology of vegetation. Similarly, improved accuracy can be obtained from dynamic global vegetation models (DGVMs) through the construction of large data sets (cf. Wright et al., 2004; Kattge et al., 2011) that include a representation of groundwater-dependent ecosystems.

A second feature apparent in the response function of Fig. 8 is the large $R^{2}$ of the sigmoidal regression, reflecting the relatively high degree of confidence in this threshold response. The response curve further suggests that extraction of groundwater beyond 7-9 $\mathrm{m}$ depth is likely to result in significant changes in ecosystem structure and function. Although we cannot pinpoint the exact breakpoint with precision, it is clearly apparent that a breakpoint does occur in the data. Furthermore, two recent reviews based on water balance concluded that groundwater uptake ceased when depths exceeded $7.5 \mathrm{~m}$ (Benyon et al., 2006) or 8-10 m (O'Grady 
Table 4. The meaning of the abbreviations/traits used in Fig. 7.

\begin{tabular}{ll}
\hline Abbreviation & Explanation/definition \\
\hline$\Psi_{\mathrm{TLP}}$ & The water potential of leaves at which turgor is zero \\
$\prod_{100}$ & The solute potential at a relative water content of $100 \%$ \\
RWC $_{\mathrm{TLP}}$ & The relative water content at which leaf turgor is zero \\
SWD & The saturated water content of wood \\
$K_{\mathrm{S}}$ & Sapwood-specific hydraulic conductivity of branch xylem \\
$K_{\mathrm{L}}$ & Leaf-specific hydraulic conductivity of branch xylem \\
PLC $_{50}$ & The water potential at which $50 \%$ of the hydraulic conductivity is lost \\
PLC 88 & The water potential at which $88 \%$ of the hydraulic conductivity is lost \\
$H_{\mathrm{V}}$ & Huber value: the ratio of leaf area to sapwood area \\
BA & Total basal area of trees within a plot \\
LAI & Leaf area index of a stand of trees \\
AGB & Above-ground biomass \\
ANPP & Above-ground net primary productivity \\
WUE & Water-use efficiency; calculated as the ratio of ANPP/stand water use \\
Height & Average height of the trees in a plot \\
Water use & Rates of stand water use; up-scaled from sap flow measurements \\
Stem density & The number of trees per hectare \\
Litterfall & Rates of annual litterfall within a plot \\
\hline
\end{tabular}

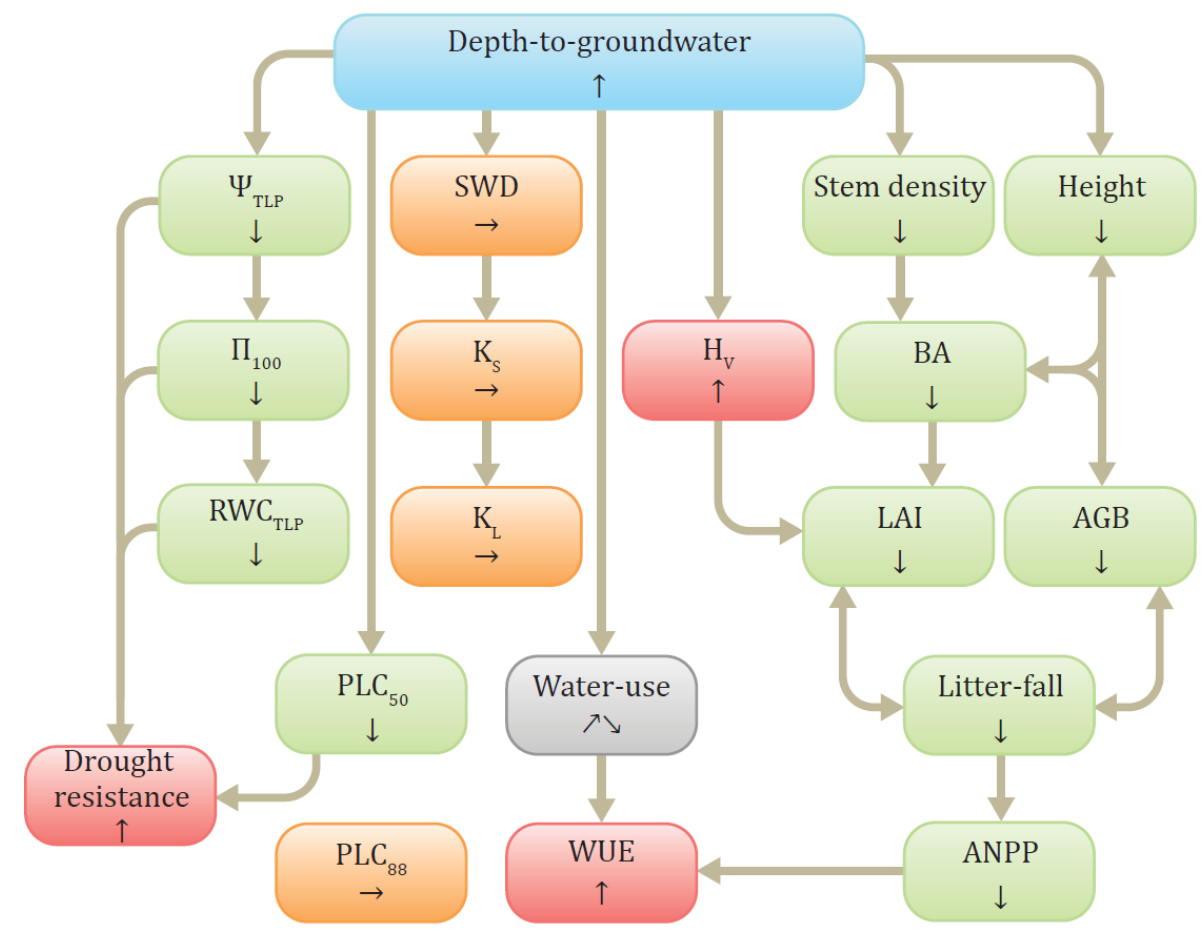

Figure 7. A summary of the traits examined and the general trend in response of those traits to increased depth-to-groundwater along a natural topographic gradient. Upward/downward pointing arrows within a coloured text box indicate increasing/decreasing values of the plant trait as depth-to-groundwater increases. Horizontal arrows indicate no change. Table 4 provides the definition of all abbreviations used in this figure.

et al., 2010), whilst Cook et al. (1998) established a limit of approximately $8 \mathrm{~m}$ for a Eucalypt savanna. Finally, Kath et al. (2014) identified thresholds of groundwater depth across 118 sites in south-eastern Australia for two tree species rang- ing from 12.1 to $26.6 \mathrm{~m}$, further supporting our identification of a breakpoint in the responses of trees to groundwater depth. Such a strong response, consistent across multiple 


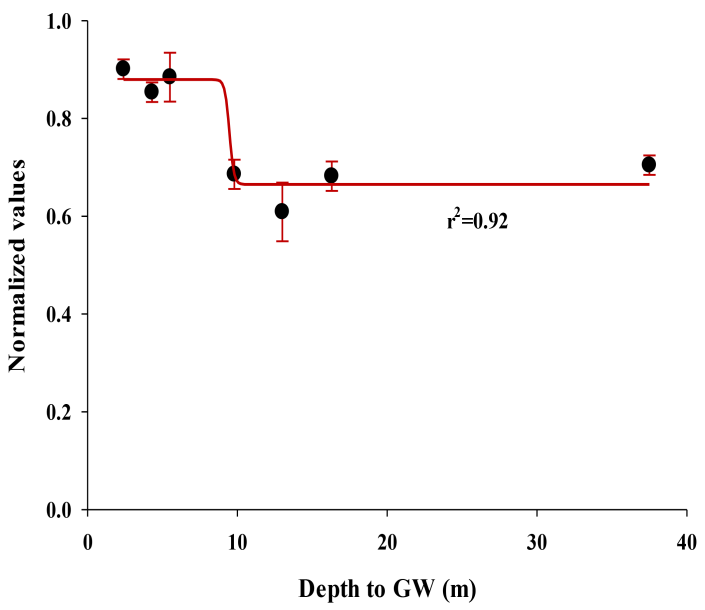

Figure 8. Ecosystem response to increase in depth-togroundwater, fitted with four-parameter sigmoidal function. From Zolfaghar (2014).

traits, should provide a strong management signal to guide future groundwater abstraction.

\subsection{Co-ordination across traits}

Some plant traits are a better indicator of plant sensitivity to water stress than others. Leaf water potential at turgor loss is recognised as a physiological measure of plant sensitivity to water stress (McDowell et al., 2008). Similarly, measurements of vulnerability to xylem cavitation and safety margins are critical determinants of drought tolerance (Markesteijn et al., 2011; Sperry et al., 2008). Safety margins are equal to the difference between minimum daily branch water potential and PLC 50 (Meinzer et al., 2008; Sperry et al., 2008). A strong linear correlation between these two traits (Fig. 9) in the Kangaloon study (Zolfaghar, 2014) reveals co-ordination in the response of leaf (cell trait) and xylem (branch trait) anatomy, as has been observed previously in a study of eight tropical dry forest species (Brodribb et al., 2003). This relationship indicates that as depth-to-groundwater increased, sensitivity to drought at both leaf cell and branch scale decreased (lower leaf water potential is needed to reach the turgor loss point, and $\mathrm{PLC}_{50}$ declined).

\section{Concluding remarks}

The existence of GDEs has been known for several centuries. The ecological, social, cultural and economic importance of GDEs, however, has only been understood more recently. Whilst inferential methods were the main means for determining the presence/location of GDEs for many decades, these have now been replaced by more direct methodologies which include the use of stable isotopes and hourly direct measurements of fluctuations in shallow groundwater depth. The most revolutionary recent development has, per-

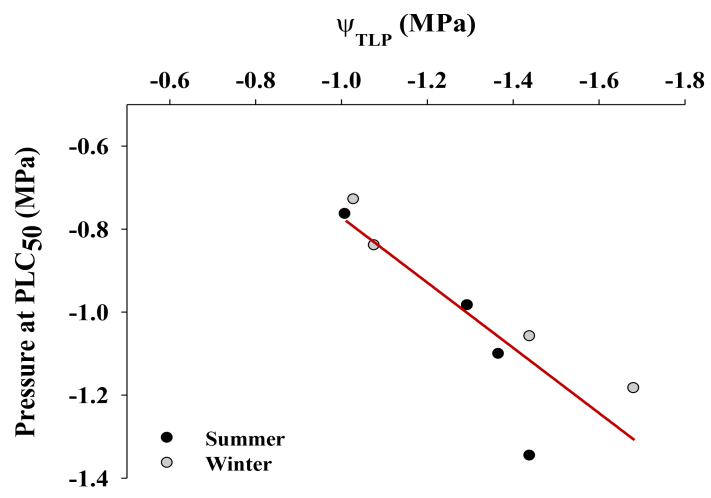

Figure 9. Co-ordination in the response of a leaf-scale and branchscale trait and drought sensitivity. From Zolfaghar (2014).

haps, been the application of remote sensing techniques to identify the location of GDEs but also to reveal key features of their functional behaviour.

Increasing frequencies, spatial and temporal extent and severity of drought and resulting drought-induced mortality of forests have been recorded extensively (Dai, 2011; Eamus et al., 2013) in the past two decades. Climate-changeinduced changes in rainfall distribution and amounts pose a new stress to both groundwater resources and associated GDEs. For the first time, remotely sensed information on both the structure (e.g. LAI) and functioning (e.g. rates of water use and primary productivity) of GDEs are now available across several decades. The challenge now is to use this long history of remotely sensed and meteorological data as a unique natural experiment to determine response functions of multiple GDEs to changes in climate (and groundwater depth) globally to inform both the science of ecology and the practical needs of water and land resource managers into the future.

Edited by: P. Saco

\section{References}

Abudu, S., Bawazir, A. S., and King, J. P.: Infilling Missing Daily Evapotranspiration Data Using Neural Networks, J. Irrig. Drain. Eng., 136, 317-325, doi:10.1061/(asce)ir.1943-4774.0000197, 2010.

Adams, H. D. and Kolb, T. E.: Tree growth response to drought and temperature in a mountain landscape in northern Arizona, USA, J. Biogeogr., 32, 1629-1640, doi:10.1111/j.13652699.2005.01292.x, 2005.

Aguilar, C., Zinnert, J. C., Jose Polo, M., and Yound, D. R.: NDVI as an indicator for changes in water availability to woody vegetation, Ecol. Appl., 23, 290-300, 2012.

Ajami, H., Meixner, T., Maddock, T., Hogan, J. F., and Guertin, P.: Impact of land-surface elevation and riparian evapotranspiration seasonality on groundwater budget in MODFLOW models, 
Hydrogeol. J., 19, 1181-1188, doi:10.1007/s10040-011-0743-0, 2011.

Ajami, H., Maddock, T., Meixner, T., Hogan, J. F., and Guertin, D. P.: RIPGIS-NET: A GIS tool for riparian groundwater evapotranspiration in MODFLOW, Ground Water, 50, 154-158, doi:10.1111/j.1745-6584.2011.00809.x, 2012.

Akasheh, O. Z., Neale, C. M. U., and Jayanthi, H.: Detailed mapping of riparian vegetation in the middle Rio Grande River using high resolution multi-spectral airborne remote sensing, J. Arid Environ., 72, 1734-1744, 2008.

Allen, R. G., Pereira, L. S., Raes, D., and Smith, M.: Crop evapotranspiration: Guidelines for computing crop requirements, Irrigation and Drainage Paper No. 56, FAO, Rome, Italy, 1998.

Amlin, N. and Rood, S.: Drought stress and recovery of riparian cottonwoods due to water table alteration along Willow Creek, Alberta, Trees Struct. Funct., 17, 351-358, 2003.

Baird, K. J. and Maddock, T.: Simulating riparian evapotranspiration: A new methodology and application for groundwater models, J. Hydrol., 312, 176-190, 2005.

Baird, K. J., Stromberg, J. C., and Maddock, T.: Linking riparian dynamics and groundwater: An ecohydrologic approach to modeling groundwater and riparian vegetation, Environ. Manage., 36, 551-564, 2005.

Baldocchi, D. D. and Ryu, Y.: A synthesis of forest evaporation fluxes - from days to years - as measured with eddy covariance, in: Forest Hydrology and Biogeochemistry: Synthesis of Past Research and Future Directions, edited by: Levia, D. F., CarlyleMoses, D., and Tanaka, T., Springer Sciences + Business Media B. V., Dordrecht, the Netherlands, 101-116, 2011.

Baldocchi, D. D. and Vogel, C. A.: Energy and $\mathrm{CO}_{2}$ flux densities above and below a temperate broad-leaved forest and a boreal pine forest, Tree Physiol., 16, 5-16, 1996.

Barron, O. V., Emelyanova, I., van Niel, T. G., Pollock, D., and Hodgson, G.: Mapping groundwater dependent ecosystems using remote sensing measures of vegetation and moisture dynamics, Hydrol. Process., 28, 372-385, 2014.

Bauer, P., Thabeng, G., Stauffer, F., and Kinzelbach, W.: Estimation of the evapotranspiration rate from diurnal groundwater level fluctuations in the Okavango Delta, Botswana, J. Hydrol., 288, 344-355, 2004.

Benyon, R. G. and Doody, T. M.: Water Use by Tree Plantations in South East South Australia. CSIRO Forestry and Forest Products Technical Report Number 148, CSIRO, Mount Gambier SA, 2004.

Benyon, R. G., Theiveyanathan, S., and Doody, T. M.: Impacts of tree plantations on groundwater in south-eastern Australia, Aust. J. Bot., 54, 181-192, doi:10.1071/bt05046, 2006.

Bogino, S. M. and Jobbagy, E. G.: Climate and groundwater effects on the establishment, growth and death of Prosopis caldenia trees in the Pampas (Argentina), Forest Ecol. Manage., 262, 1766-1774, doi:10.1016/j.foreco.2011.07.032, 2011.

Brodribb, T. J., Holbrook, N. M., Edwards, E. J., and Gutierrez, M. V.: Relations between stomatal closure, leaf turgor and xylem vulnerability in eight tropical dry forest trees, Plant Cell Environ., 26, 443-450, 2003.

Brown, J., Bach, L., Aldous, A., Wyers, A., and DeGagne, J.: Groundwater-dependent ecosystems in Oregon: an assessment of their distribution and associated threats, Front. Ecol. Environ., 9, 97-102, 2010.
Brown, L.: Water tables falling and rivers running dry: international situation, Int. J. Environ., 3, 1-5, 2007.

Brunner, P., Franssen, H.-J. H., Kgotlhang, L., Bauer-Gottwein, P., and Kinzelbach, W.: How can remote sensing contribute in groundwater modeling?, Hydrogeol. J., 15, 5-18, 2007.

Budyko, M. I.: Climate and life, Academic Press, San Diego, CA, 508 pp., 1974.

Busch, D. E., Ingraham, N. L., and Smith, S. D.: Water uptake in woody riparian phreatophytes of the Southwestern United States: a stable isotope study, Ecol. Appl., 2, 450-459, 1992.

Butler, J. J., Kluitenberg, G. J., Whittemore, D. O., Loheide, S. P., Jin, W., Billinger, M. A., and Zhan, X. Y.: A field investigation of phreatophyte-induced fluctuations in the water table, Water Resour. Res., 43, W02404, doi:10.1029/2005WR004627, 2007.

Campos, G. E. P., Moran, M. S., Huete, A., Zhang, Y., Bresloff, C., Huxman, T. E., Eamus, D., Bosch, D. D., Buda, A. R., and Gunter, S. A.: Ecosystem resilience despite large-scale altered hydroclimatic conditions, Nature, 494, 349-352, 2013.

Canham, C. A., Froend, R. H., and Stock, W. D.: Water stress vulnerability of four Banksia species in contrasting ecohydrological habitats on the Gnangara Mound, Western Australia, Plant Cell Environ., 32, 64-72, 2009.

Canham, C. A., Froend, R. H., Stock, W. D., and Davies, M.: Dynamics of phreatophyte root growth relative to a seasonally fluctuating water table in a Mediterranean-type environment, Oecologia, 170, 909-916, 2012.

Carlson, T. N. and Ripley, D. A.: On the relation between NDVI, fractional vegetation cover, and leaf area index, Remote Sens. Environ., 62, 241-252, doi:10.1016/s0034-4257(97)00104-1, 1997.

Carter, J. L. and White, D. A.: Plasticity in the Huber value contributes to homeostasis in leaf water relations of a mallee Eucalypt with variation to groundwater depth, Tree Physiol., 29, 1407-1418, doi:10.1093/treephys/tpp076, 2009.

Cernusak, L. A., Marshall, J. D., Comstock, J. P., and Balster, N. J.: Carbon isotope discrimination in photosynthetic bark, Oecologia, 128, 24-35, doi:10.1007/s004420100629, 2001.

Chimner, R. A. and Cooper, D. J.: Using stable oxygen isotopes to quantify the water source used for transpiration by native shrubs in the San Luis Valley, Colorado USA, Plant Soil, 260, 225-236, doi:10.1023/B:PLSO.0000030190.70085.e9, 2004.

Cleverly, J. R.: Water use by Tamarix, in: Tamarix. A Case Study of Ecological Change in the American West, Sher, A. and Quigley, M. F., Oxford University Press, New York, NY, 85-98, 2013.

Cleverly, J. R., Smith, S. D., Sala, A., and Devitt, D. A.: Invasive capacity of Tamarix ramosissima in a Mojave Desert floodplain: the role of drought, Oecologia, 111, 12-18, 1997.

Cleverly, J. R., Dahm, C. N., Thibault, J. R., Gilroy, D. J., and Coonrod, J. E. A.: Seasonal estimates of actual evapotranspiration from Tamarix ramosissima stands using threedimensional eddy covariance, J. Arid Environ., 52, 181-197, doi:10.1006/jare.2002.0972, 2002.

Cleverly, J. R., Dahm, C. N., Thibault, J. R., McDonnell, D. E., and Coonrod, J. E. A.: Riparian ecohydrology: Regulation of water flux from the ground to the atmosphere in the Middle Rio Grande, New Mexico, Hydrol. Process., 20, 3207-3225, 2006.

Clifton, C. A. and Evans, R.: Environmental water requirements to maintain groundwater dependent ecosystems, Environmental 
Flows Initiative Technical Report Number 2, Commonwealth of Australia, Canberra, 2001.

Cocozza, C., Giovannelli, A., Traversi, M. L., Castro, G., Cherubini, P., and Tognetti, R.: Do tree-ring traits reflect different water deficit responses in young poplar clones (Populus $\times$ canadensis Monch 'I-214' and P. deltoides 'Dvina')?, Trees Struct. Funct., 25, 975-985, doi:10.1007/s00468-011-0572-8, 2011.

Conejero, W., Alarcón, J. J., García-Orellana, Y., Abrisqueta, J. M., and Torrecillas, A.: Daily sapflow and maximum daily trunk shrinkage measurements for diagnosing water stress in early maturing peach trees during the post harvest period, Tree Physiol., 27, 81-88, 2007.

Conejero, W., Mellisho, C. D., Ortuno, M. F.: Using trunk diameter sensors for regulated irrigation scheduling in early maturing peach trees, Environ. Exp. Bot., 71, 409-415, 2011.

Contreras, S., Jobbagy, E. G., Villagra, P. E., Nosetto, M. D., and Puigdefabregas, J.: Remote sensing estimates of supplementary water consumption by arid ecosystems of central Argentina, J. Hydrol., 397, 10-22, 2011.

Cook, P. G. and O'Grady, A. P.: Determining soil and ground water use of vegetation from heat pulse, water potential and stable isotope data, Oecologia, 148, 97-107, doi:10.1007/s00442-0050353-4, 2006.

Cook, P. G., Hatton, T. J., Pidsley, D., Herczeg, A. L., Held, A., O'Grady, A., and Eamus, D: Water balance of a tropical woodland ecosystem, northern Australia: a combination of micro-meteorological, soil physical and groundwater chemical approaches, J. Hydrol., 210, 161-177, doi:10.1016/S00221694(98)00181-4, 1998.

Cooper, D. J., D’Amico, D., and Scott, M.: Physiological and morphological response patterns of Populus deltoides to alluvial groundwater pumping, Environ. Manage., 31, 215-226, 2003.

Cooper, D. J., Sanderson, J. S., Stannard, D. I., and Groeneveld, D. P.: Effects of long-term water table drawdown on evapotranspiration and vegetation in an arid region phreatophyte community, J. Hydrol., 325, 21-34, 2006.

Dahm, C. N., Cleverly, J. R., Coonrod, J. E. A., Thibault, J. R., McDonnell, D. E., and Gilroy, D. F.: Evapotranspiration at the land/water interface in a semi-arid drainage basin, Freshwater Biol., 47, 831-843, 2002.

Dai, A.: Drought under global warming: a review, Wiley Interdisciplinary Reviews - Climate Change, 2, 45-65, 2011.

Dawson, T. E. and Ehleringer, J. R.: Streamside trees that do not use stream water, Nature, 350, 335-337, doi:10.1038/350335a0, 1991.

Devitt, D. A., Sala, A., Smith, S. D., Cleverly, J. R., Shaulis, L. K., and Hammett, R.: Bowen ratio estimates of evapotranspiration for Tamarix ramosissima stands on the Virgin River in southern Nevada, Water Resour. Res., 34, 2407-2414, 1998.

Di Tomaso, J. M.: Impact, biology, and ecology of saltcedar (Tamarix spp.) in the southwestern United States, Weed Technol., 12, 326-336, 1998.

Doble, R., Simmons, C., Jolly, I., and Walker, G.: Spatial relationships between vegetation cover and irrigation-induced groundwater discharge on a semi-arid floodplain, Australia, J. Hydrol., 329, 75-97, doi:10.1016/j.jhydrol.2006.02.007, 2006.

Donohue, R. J., Roderick, M. L., and McVicar, T. R.: On the importance of including vegetation dynamics in Budyko's hydrological model, Hydrol. Earth Syst. Sci., 11, 983-995, doi:10.5194/hess11-983-2007, 2007.

Doody T. M., Benyon, R. G., Theiveyanathan, S., Koul, V., and Stewart, L.: Development of pan coefficients for estimating evapotranspiration from riparian woody vegetation, Hydrol. Process., 28, 2129-2149, doi:10.1002/hyp.9753, 2014.

Drake, P. L. and Franks, P. J.: Water resource partitioning, stem xylem hydraulic properties, and plant water use strategies in a seasonally dry riparian tropical rainforest, Oecologia, 137, 321329, doi:10.1007/s00442-003-1352-y, 2003.

Drake, P. L., Coleman, B. F., and Vogwill, R.: The response of semiarid ephemeral wetland plants to flooding: linking water use to Hydrol. Proc., Ecohydrology, 6, 852-862, 2013.

Dresel, P. E., Clark, R., Cheng, X., Reid, M., Terry, A., Fawcett, J., and Cochrane, D.: Mapping Terrestrial GDEs: Method development and example output. Victoria Department of Primary Industries, Melbourne, VIC., 66 pp., 2010.

Drew, D. M. and Downes, G. M.: The use of precision dendrometers in research on daily stem size and wood property variation: A review, Dendrochronologia, 27, 169-172, 2009.

Drew, D. M., O’Grady, A. P., Downes, G. M., Read, J., and Worledge, D.: Daily patterns of stem size variation in irrigated and unirrigated Eucalyptus globulus, Tree Physiol., 28, 15731581, 2008.

Eagleson, P. S.: Climate, soil and vegetation: 1. Introduction to water balance dynamics, Water Resour. Res., 14, 705-712, 1978.

Eamus, D., Hutley, L. B., and O'Grady, A. P.: Daily and seasonal patterns of carbon and water fluxes above a north Australian savanna, Tree Physiol., 21, 977-988, 2001.

Eamus, D., Haton, T., Cook, P., and Colvin, C.: Ecohydrology: vegetation function, water and resource manangement, CSIRO, Melbourne, 2006a.

Eamus, D., Froend, R., Loomes, R., Hose, G., and Murray, B.: A functional methodology for determining the groundwater regime needed to maintain the health of groundwater-dependent vegetation, Aust. J. Bot., 54, 97-114, 2006 b.

Eamus, D., Boulain, N., Cleverly, J., and Breshears, D. D.: Global change-type drought induced tree mortality: vaour pressure deficit is more important than temperature per se in causing decline in tree health, Ecol. Evol., 3, 2711-2729, 2013.

Ehleringer, J. R. and Dawson, T. E.: Water uptake by plants: perspectives from stable isotope composition, Plant Cell Environ., 15, 1073-1082, 1992.

Ellis, T. W. and Hatton, T. J.: Relating leaf area index of natural eucalypt vegetation to climate variables in southern Australia, Agr. Water Manage., 95, 743-747, 2008.

Elmahdi, A. and McFarlane, D.: Integrated multi-agency framework: sustainable water management, Proc. Inst. Civ. Eng. Water Manage., 165, 313-326, doi:10.1680/wama.11.00003, 2012.

Elmore, A. J., Manning, S. J., Mustard, J. F., and Craine, J. M.: Decline in alkali meadow vegetation cover in California: the effects of groundwater extraction and drought, J. Appl. Ecol., 43, 770-779, 2006.

Engel, V., Jobbagy, E. G., Stieglitz, M., Williams, M., and Jackson, R. B.: Hydrological consequences of eucalyptus afforestation in the argentine pampas, Water Resour. Res., 41, W10409, doi:10.1029/2004wr003761, 2005. 
Everitt, J. H. and DeLoach, C. J.: Remote sensing of Chinese Tamarisk (Tamarix chinensis) and associated vegetation, Weed Science, 38, 273-278, 1990.

Everitt, J. H., Judd, F. W., Escobar, D. E., Alaniz, M. A., Davis, M. R., and MacWhorter, W.: Using remote sensing and spatial information technologies to map sabal palm in the lower Rio Grande Valley of Texas, Southw. Natural., 41, 218-226, 1996.

Fahle, M. and Dietrich, O.: Estimation of evapotranspiration using diurnal groundwater level fluctuations: Comparison of different approaches with groundwater lysimeter data, Water Resour. Res., 50, 273-286, doi:10.1002/2013wr014472, 2014.

February, E. C., Higgins, S. I., Newton, R., and West, A. G.: Tree distribution on a steep environmental gradient in an arid savanna, J. Biogeogr., 34, 270-278, 2007.

Feikema, P. M., Morris, J. D., and Connell, L. D.: The water balance and water sources of a Eucalyptus plantation over shallow saline groundwater, Plant Soil, 332, 429-449, 2010.

Ford, C. R., Mitchell, R. J., and Teskey, R. O.: Water table depth affects productivity, water use and the response to nitrogen addition in a savvan system, Can. J. Forest Res., 38, 2118-2127, 2008.

Froend, R. H. and Drake, P. L.: Defining phreatophyte response to reduced water availability: preliminary investigations on the use of xylem cavitation vulnerability in Banksia woodland species, Aust. J. Bot., 54, 173-179, 2006.

Froend, R. H. and Sommer, B.: Phreatophytic vegetation response to climatic and abstraction-induced GW drawdown: examples of long-term spatial and temporal variability in community response, Ecol. Eng., 36, 1191-1200, 2010.

Galindo, A., Rodrigues, P., Mellisho, C. D., Torrecillas, E., Moriana, A., Cruz, Z. N., Conejero, W., Moreno, F., and Terrecillas, A.: Assessment of discreetly measured indicators and maximum daily trunk shrinkage for detecting water stress in pomegranate trees, Agr. Forest Meteorol., 180, 58-65, 2013.

Gamon, J., Field, C., Goulden, M., Griffin, K., Hartley, A., Joel, G., Penuelas, J., and Valentini, R.: Relationships between NDVI, canopy structure, and photosynthesis in 3 Californian vegetation types, Ecol. Appl., 5, 28-41, 1995.

Gay, L. W. and Fritschen, L. J.: An energy budget analysis of water use by saltcedar, Water Resour. Res., 15, 1589-1592, 1979.

Gazal, R. M., Scott, R. L., Goodrich, D. C., and Williams, D. G.: Controls on transpiration in a semiarid riparian cottonwood forest, Ag. Forest Meterol., 137, 56-67, 2006.

Gessler, A., Brandes, E., Buchmann, N., Helle, G., Rennenberg, H., and Barnard, R. L.: Tracing carbon and oxygen isotope signals from newly assimilated sugars in the leaves to the tree-ring archive, Plant Cell Environ., 32, 780-795, doi:10.1111/j.13653040.2009.01957.x, 2009.

Giantomasi, M. A., Roig-Juñent, F. A., and Villagra, P. E.: Use of differential water sources by Prosopis flexuosa DC: a dendroecological study, Plant Ecol., 214, 11-27, doi:10.1007/s11258-0120141-2, 2012.

Giordano, M.: Global groundwater? Issue and solutions, Ann. Rev. Environ. Res. 34, 153-178.2009.

Glazer, A. N. and Likens, G. E.: The water table: the shifting foundation of life on land, Ambio, 41, 657-669, 2012.

Gleick, P. and Palaniappan, M.: Peak water limits to freshwater withdrawal and use, P. Natl. Acad. Sci., 107, 11155-11162, 2010.
Glenn, E. P., Huete, A. R., Nagler, P. L., Hirschboeck, K. K., and Brown, P.: Integrating remote sensing and ground methods to estimate evapotranspiration, Crit. Rev. Pl. Sci., 26, 139-168, doi:10.1080/07352680701402503, 2007.

Glenn, E. P., Nagler, P. L., and Huete, A. R.: Vegetation Index Methods for Estimating Evapotranspiration by Remote Sensing, Surv Geophys., 31, 531-555, doi:10.1007/s10712-010-9102-2, 2010.

Gonzalez, E., Gonzalex-Sanchis, M., Comin, F. A., and Muller, E.: Hydrologic thresholds for riparian forest conservation in a regulated large Mediterranean river, River Res. Appl., 28, 81-80, 2012.

Goodrich, D. C., Chehbouni, A., Goff, B., MacNish, B., Maddock, T., Moran, S., Shuttleworth, W. J., Williams, D. G., Watts, C., Hipps, L. H., Cooper, D. I., Schieldge, J., Kerr, Y. H., Arias, H., Kirkland, M., Carlos, R., Cayrol, P., Kepner, W., Jones, B., Avissar, R., Begue, A., Bonnefond, J. M., Boulet, G., Branan, B., Brunel, J. P., Chen, L. C., Clarke, T., Davis, M. R., DeBruin, H., Dedieu, G., Elguero, E., Eichinger, W. E., Everitt, J., Garatuza-Payan, J., Gempko, V. L., Gupta, H., Harlow, C., Hartogensis, O., Helfert, M., Holifield, C., Hymer, D., Kahle, A., Keefer, T., Krishnamoorthy, S., Lhomme, J. P., Lagouarde, J. P., Lo Seen, D., Luquet, D., Marsett, R., Monteny, B., Ni, W., Nouvellon, Y., Pinker, R., Peters, C., Pool, D., Qi, J., Rambal, S., Rodriguez, J., Santiago, F., Sano, E., Schaeffer, S. M., Schulte, M., Scott, R., Shao, X., Snyder, K. A., Sorooshian, S., Unkrich, C. L., Whitaker, M., and Yucel, I.: Preface paper to the Semi-Arid Land-Surface-Atmosphere (SALSA) Program special issue, Agr. Forest Meteorol., 105, 3-20, 2000a.

Goodrich, D. C., Scott, R., Qi, J., Goff, B., Unkrich, C. L., Moran, M. S., Williams, D., Schaeffer, S., Snyder, K., MacNish, R., Maddock, T., Pool, D., Chehbouni, A., Cooper, D. I., Eichinger, W. E., Shuttleworth, W. J., Kerr, Y., Marsett, R., and Ni, W.: Seasonal estimates of riparian evapotranspiration using remote and in situ measurements, Agr. Forest Meterol., 105, 281-309, 2000b.

Gou, S., Gonzales, S., and Miller, G.: Mapping potential groundwater-dependent ecosystems for sustainable management, Ground Water, 53, 99-110, 2015.

Gribovszki, Z., Kalicz, P., Szilagyi, J., and Kucsara, M.: Riparian zone evapotranspiration estimation from diurnal groundwater level fluctuations, J. Hydrol., 349, 6-17, 2008.

Gribovszki, Z., Szilagyi, J., and Kalicz, P.: Diurnal fluctuations in shallow groundwater levels and streamflow rates and their interpretation - A review, J. Hydrol., 385, 371-383, doi:10.1016/j.jhydrol.2010.02.001, 2010.

Gries, D., Zeng, F., Foetzki, A., Arndt, S. K., Bruelheide, H., Thomas, F. M., Zhang, X., and Runge, M.: Growth and water relations of Tamarix ramosissima and Populus euphratica on Taklamakan desert dunes in relation to depth to a permanent water table, Plant Cell Environ., 26, 725-736, 2003.

Groeneveld, D. P.: Remotely-sensed groundwater evapotranspiration from alkali scrub affected by declining water table, J. Hydrol., 358, 294-303, 2008.

Groeneveld, D. P. and Baugh, W. M.: Correcting satellite data to detect vegetation signal for eco-hydrologic analyses, J. Hydrol., 344, 135-145, 2007.

Groeneveld, D. P., Baugh, W. M., Sanderson, J. S., and Cooper, D. J.: Annual groundwater evapotranspiration mapped from single satellite scenes, J. Hydrol., 344, 146-156, 2007. 
Groom, B. P., Froend, R. H., and Mattiske, E. M.: Impact of groundwater abstraction on Banksia woodland, Swan Coastal Plain, Western Australia, Ecol. Manage. Restor., 1, 117-124, 2000.

Hanson, R. T., Dettinger, M. D., and Newhouse, M. W.: Relations between climatic variability and hydrologic time series from four alluvial basins across the southwestern United States, Hydrogeol. J., 14, 1122-1146, doi:10.1007/s10040-006-0067-7, 2006.

Hatton, T. and Evans, R.: Dependence of ecosystems on groundwater and its significance to Australia, Occasional Paper No. 12/98, Land and Water Res. Res. and Dewvelopment Corporation, CSIRO, Australia, 1998.

Henry, C. M., Allen, D. M., and Huang, J.: Groundwater storage variability and annual recharge using well-hydrograph and GRACE satellite data, Hydrogeol. J., 19, 741-755, 2011.

Horton, J. L., Kolb, T. E., and Hart, S. C.: Responses of riparian trees to inter-annual variation in groundwater depth in a semiarid river basin, Plant Cell Environ., 24, 293-304, 2001.

Houborg, R., Rodell, M., Li, B., Reichle, R., and Zaitchik, B. F.: Drought indicators based on model assimilated GRACE terrestrial water storage observations, Water Resour Res., 48, W07525, doi:10.1029/2011WR011291, 2012.

Howard, J. and Merrifield, M.: Mapping groundwater dependent ecosystems in California, PLoS ONE, 5, e11249, doi:10.1371/journal.pone.0011249, 2010.

Huete, A., Didan, K., Miura, T., Rodriguez, E. P., Gao, X., and Ferreira, L. G.: Overview of the radiometric and biophysical performance of the MODIS vegetation indices, Remote Sens. Environ., 83, 195-213, doi:10.1016/s0034-4257(02)00096-2, 2002.

Hultine, K. R. and Bush, S. E.: Ecohydrological consequences of non-native riparian vegetation in the southwestern United States: A review from an ecophysiological perspective, Water Resour Res., 47, W07542, doi:10.1029/2010wr010317, 2011.

Hultine, K. R., Bush, S. E., and Ehleringer, J. R.: Ecophysiology of riparian cottonwood and willow before, during, and after two years of soil water removal, Ecol. Appl., 20, 347-361, doi:10.1890/09-0492.1, 2010

Jin, X. M., Schaepman, M. E., Clevers, J. G., Su, Z. B., and Hu, G.: Groundwater depth and vegetation in the Ejina area, China, Arid Land Res. Manage., 25, 194-199, 2011.

Jobbagy, E. G., Nosetto, M. D., Villagra, P. E., and Jackson, R. B.: Water subsidies from montains to deserts:their roile in sustaining groundwater fed oases in a sandy landscape, Ecol. Appl., 21, 678-694, 2011.

Jung, M., Reichstein, M., Margolis, H. A., Cescatti, A., Richardson, A. D., Arain, M. A., Arneth, A., Bernhofer, C., Bonal, D., Chen, J. Q., Gianelle, D., Gobron, N., Kiely, G., Kutsch, W., Lasslop, G., Law, B. E., Lindroth, A., Merbold, L., Montagnani, L., Moors, E. J., Papale, D., Sottocornola, M., Vaccari, F., and Williams, C.: Global patterns of land-atmosphere fluxes of carbon dioxide, latent heat, and sensible heat derived from eddy covariance, satellite, and meteorological observations, J. Geophys. Res., 116, G00J07, doi:10.1029/2010jg001566, 2011.

Kanniah, K. D., Beringer, J., and Hutley, L. B.: Response of savanna gross primary productivity to interannual variability in rainfall: Results of a remote sensing based light use efficiency model, Prog. Phys. Geogr., 37, 642-663, 2013.

Kath, J., Reardon-Smith, K., Le Brocque, A. F., Dyer, F. J., Dafny, E., Fritz, L., and Batterham, M.: Groundwater decline and tree change in floodplain landscapes: Identifying non-linear threshold responses in canopy condition, Global Ecol. Conserv., 2, 148160, 2014.

Kattge, J., Diaz, S., Laborel, S., et al.: TRY - a global database of plant traints, Global Change Biol., 17, 2905-2935, 2011.

Kelliher, F. M., Kirkham, M. B., and Tauer, C. G.: Stomatal resistance, transpiration and growth of drought-stressed eastern cottonwood, Can. J. Forest Res. 10, 447-451, 1980.

Kelliher, F. M., Kostner, B. M. M., Hollinger, D. Y., Byers, J. N., Hunt, J. E., McSeveny, T. M., Meserth, R., Weir, P. L., and Schulze, E. D.: Evaporation, xylem sapflow and tree transpiration in a New Zealand broad-leaved forest, Agr. Forest Meteorol., 62, 53-73, doi:10.1016/0168-1923(92)90005-o, 1992.

Kochendorfer, J., Castillo, E. G., Haas, E., Oechel, W. C., and Paw U, K. T.: Net ecosystem exchange, evapotranspiration and canopy conductance in a riparian forest, Agr. Forest Meteorol., 151, 544-553, 2011.

Kranjcec, J., Mahoney, J. M., and Rood, S. B.: The responses of three riparian cottonwood species to water table decline, Forest Ecol. Manage., 110, 77-87, 1998.

Kray, J. Cooper, D., and Sanderson, J.: Groundwater use by native plants in response to changes in precipitation in an intermountain basin, J. Arid Environ.,83, 25-34, 2012.

Lageard, J. G. A. and Drew, I. B.: Hydrogeomorphic control on tree growth responses in the Elton area of the Cheshire Saltfield, UK, Geomorphology, 95, 158-171, doi:10.1016/j.geomorph.2007.05.017, 2008.

Lamontagne, S., Cook, P. G., O' Grady, A., and Eamus, D.: Groundwater use by vegetation in a tropical savanna riparian zone (Daly River, Australia), J. Hydrol., 310, 280-293, 2005.

Lautz, L. K.: Estimating groundwater evapotranspiration rates using diurnal water-table fluctuations in a semi-arid riparian zone, Hydrogeol. J., 16, 483-497, 2008.

Leblanc, M. J., Leduc, C., Razack, M., Lemoalle, J., Dagorne, D., and Mofor, L.: Application of remote sensing and GIS for groundwater modelling of large semiarid areas: example of the Lake Chad Basin, Africa. Hydrology of Mediterranean and Semiarid Regions Conference, Montpieller, France, April 2003, IAHS (Red Books Series), Wallingford, UK, 186-192, $2003 \mathrm{a}$.

Leblanc, M. J., Razack, M., Dagorne, D., Mofor, L., and Jones, C.: Application of Meteosat thermal data to map soil infiltrability in the central part of the Lake Chad basin, Africa, Geophys. Res. Lett., 30, 1998, doi:10.1029/2003gl018094, 2003b.

Leblanc, M. J., Tregoning, P., Ramillien, G., Tweed, S. O., and Fakes, A.: Basin-scale, integrated observations of the early 21 st century multiyear drought in southeast Australia, Water Resour. Res., 45, W04408, doi:10.1029/2008WR007333, 2009.

Leffler, A. J. and Evans, A. S.: Variation in carbon isotope composition among years in the riparian tree Populus fremontii, Oecologia, 119, 311-319, 1999.

Li, F. and Lyons, T.: Estimation of regional evapotranspiration through remote sensing, J. Appl. Meteorol., 38, 1644-1654, 1999.

Lite, S. J. and Stromberg, J. C.: Surface water and ground-water thresholds for maintaining Populus-Salix forests, San Pedro River, Arizona, Biol. Conserv., 125, 153-167, 2005.

Logsdon, S. D., Schilling, K. E., Hernandez-Ramirez, G., Prueger, J. H., Hatfield, J. L., and Sauer, T. J.: Field estimation of specific yield in a central Iowa crop field, Hydrol. Process., 24, 13691377, doi:10.1002/hyp.7600, 2010. 
Loheide, S. P.: A method for estimating subdaily evapotranspiration of shallow groundwater using diurnal water table fluctuations, Ecohydrology, 1, 59-66, 2008.

Loheide, S. P. and Booth, E. G.: Effects of changing channel morphology on vegetation, groundwater, and soil moisture regimes in groundwater-dependent ecosystems, Geomorphology, 126, 364376, 2011

Loheide, S. P., Butler, J. J., and Gorelick, S. M.: Estimation of groundwater consumption by phreatophytes using diurnal water table fluctuations: A saturated-unsaturated flow assessment, Water Resour. Res., 41, W07030, doi:10.1029/2005wr003942, 2005.

Lowry, C. S. and Loheide, S. P.: Groundwater-dependent vegetation: Quantifying the groundwater subsidy, Water Resour. Res., 46, W06202, doi:10.1029/2009wr008874, 2010.

Lowry, C. S., Loheide, S. P., Moore, C. E., and Lundquist, J. D.: Groundwater controls on vegetation composition and patterning in mountain meadows, Water Resour. Res., 47, W00J11, doi:10.1029/2010wr010086, 2011.

Lv, J., Wang, X. S., Zhou, Y., Qian, K., Wan, L., Eamus, D., and Tao, Z.: Groundwater-dependent distribution of vegetation in Hailiutu River catchment, a semi-arid region in China, Ecohydrology, 6, $142-149,2012$

Ma, X., Huete, A., Yu, Q., Coupe, N. R., Davies, K., Broich, M., Ratana, P., Beringer, J., Hutley, L. B., Cleverly, J., Boulain, N., and Eamus, D.: Spatial patterns and temporal dynamics in savanna vegetation phenology across the North Australian Tropical Transect, Remote Sens. Environ., 139, 97-115, doi:10.1016/j.rse.2013.07.030, 2013.

Máguas, C., Rascher, K. G., Martins-Loução, A., Carvalho, P., Pinho, P., Ramos, M., Correia, O., and Werner, C.: Responses of woody species to spatial and temporal ground water changes in coastal sand dune systems, Biogeosciences, 8, 3823-3832, doi:10.5194/bg-8-3823-2011, 2011.

Mahoney, J. M. and Rood, S. B.: A device for studying the influence of declining water table on poplar growth and survival, Tree Physiol., 8, 305-314, 1991.

Markesteijn, L., Poorter, L., Paz, H., Sack, L., and Bongers, F.: Ecological differentiation in xylem cavitation resistance is associated with stem and leaf structural traits, Plant Cell Environ., 34, 137148, 2011.

Martinet, M. C., Vivoni, E. R., Cleverly, J. R., Thibault, J. R., Schuetz, J. F., and Dahm, C. N.: On groundwater fluctuations, evapotranspiration, and understory removal in riparian corridors, Water Resour. Res., 45, W05425, doi:10.1029/2008WR007152, 2009.

McCarroll, D. and Loader, N. J.: Stable isotopes in tree rings, Quaternary Sci. Rev., 23, 771-801, doi:10.1016/j.quascirev.2003.06.017, 2004.

McDonald, M. G. and Harbaugh, A. W.: A modular threedimensional finite-difference ground-water flow model, Department of Interior, US Geological Survey, Washington, D.C., 1988.

McDowell, N., Pockman, W. T., Allen, C. D., Breshears, D. D., Cobb, N., Kolb, T., Plaut, J., Sperry, J., West, A., Williams, D. G., and Yepez, E. A.: Mechanisms of plant survival and mortality during drought: why do some plants survive while others succumb to drought?, New Phytol., 178, 719-739, doi:10.1111/j.1469-8137.2008.02436.x, 2008.
McLendon, T., Hubbard, P. J., and Martin, D. W.: Partitioning the use of precipitation-and groundwater-derived moisture by vegetation in an arid ecosystem in California, J. Arid Environ., 72, 986-1001, 2008.

Meinzer, F. C., Campanello, P. I., Domec, J.-C., Gatti, M. G., Goldstein, G., Villalobos-Vega, R., and Woodruff, D. R.: Constraints on physiological function associated with branch architecture and wood density in tropical forest trees, Tree Physiol., 28, 16091617, 2008.

Merritt, D. M. and Bateman, H. L.: Linking stream flow and groundwater to avian habitat in a desert riparian system, Ecol. Appl., 22, 1973-1988, 2012.

Miller, G. R., Chen, X., Rubin, Y., Ma, S., and Baldocchi, D. D.: Groundwater uptake by woody vegetation in a semiarid oak savanna, Water Resour. Res., 46, W10503, doi:10.1029/2009wr008902, 2010.

Moore, G. W., Cleverly, J. R., and Owens, M. K.: Nocturnal transpiration in riparian Tamarix thickets authenticated by sap flux, eddy covariance and leaf gas exchange measurements, Tree Physiol. 28, 521-528, 2008.

Münch, Z, and Conrad, J.: Remote sensing and GIS based determination of groundwater dependent ecosystems in the Western Cape, South Africa, Hydrogeol. J., 15, 19-28, 2007.

Murray, B. R., Hose, G. C., Eamus, D., and Licari, D.: Valuation of groundwater-dependent ecosystems: a functional methodology incorporating ecosystem services, Aust. J. Bot., 54, 221229, 2006.

Nachabe, M., Shah, N., Ross, M., and Vomacka, J.: Evapotranspiration of two vegetation covers in a shallow water table environment, Soil Sci. Soc. Am. J., 69, 492-499, 2005.

Nagler, P. L., Glenn, E., Thompson, T., and Huete, A.: Leaf area index and NDVI as predictors of canopy characteristics and light interception by riparian species on the Lower Colarado River, Agr. Forest Meteorol., 116, 103-112, 2004.

Nagler, P. L., Cleverly, J., Glenn, E., Lampkin, D., Huete, A., and Wan, Z. M.: Predicting riparian evapotranspiration from MODIS vegetation indices and meteorological data, Remote Sens. Environ., 94, 17-30, 2005a.

Nagler, P. L., Scott, R. L., Westenburg, C., Cleverly, J. R., Glenn, E. P., and Huete, A. R.: Evapotranspiration on western US rivers estimated using the Enhanced Vegetation Index from MODIS and data from eddy covariance and Bowen ratio flux towers, Remote Sens. Environ., 97, 337-351, doi:10.1016/j.rse.2005.05.011, 2005b.

Nagler, P. L., Morino, K., Didan, K., Erker, J., Osterberg, J., Hultine, K. R., and Glenn, E. P.: Wide-area estimates of saltcedar (Tamarix spp.) evapotranspiration on the lower Colorado River measured by heat balance and remote sensing methods, Ecohydrology, 2, 18-33, doi:10.1002/eco.35, 2009.

Nagler, P. L., Glenn, E., Nguyen, U., Scott, R., and Doody, T.: Estimating riparian and agricultural actual evapotranspiration by reference evapotranspiration and MODIS enhanced vegetation index, Remote Sensing, 5, 3849-3871, 2013.

Naumburg, E., Mata-Gonzalez, R., Hunter, R. G., McLendon, T., and Martin, D. W.: Phreatophytic vegetation and groundwater fluctuations: a review of current research and application of ecosystem response modeling with an emphasis on great basin vegetation, Environ. Manage., 35, 726-740, doi:10.1007/s00267-004-0194-7, 2005. 
Neale, C. M. U.: Classification and mapping of riparian systems using airborne multispectral videography, Restor. Ecol., 5, 103$112,1997$.

Nemani, R. R. and Running, S. W.: Testing a theoretical climate soil leaf-area hydrological equilibrium of forests using satellite data and ecosystem simulation, Agr. Forest Meteorol., 44, 245-260, 1989.

Nippert, J. B., Butler, J. J., Kluitenberg, G. J., Whittemore, D. O., Arnold, D., Spal, S. E., and Ward, J. K.: Patterns of Tamarix water use during a record drought, Oecologia, 162, 283-292, doi:10.1007/s00442-009-1455-1, 2010.

Nosetto, M. D., Jobbagy, E. G., Toth, T., and Bella, C. M. D.: The effects of tree establishment on water and salt dynamics in naturally salt-affected grasslands, Oecologia, 152, 695-705, 2007.

Oberhuber, W., Stumbock, M., and Kofler, W.: Climate tree-growth relationships of Scots pine stands (Pinus sylvestris L.) exposed to soil dryness., Trees Struct. Funct., 13, 19-27, 1998.

O'Grady, A. P., Cook, P. G., Howe, P., and Werren, G.: Groundwater use by dominant tree species in tropical remnant vegetation communities, Aust. J. Bot., 54, 155-171, doi:10.1071/bt04179, $2006 \mathrm{a}$.

O'Grady, A. P., Eamus, D., Cook, P. G., and Lamontagne, S.: Groundwater use by riparian vegetation in the wet-dry tropics of northern Australia, Aust. J. Bot., 54, 145-154, 2006b.

O'Grady, A. P., Carter, J. L., and Holland, K.: Review of Australian groundwater discharge studies of terrestrial systems, in: Water for a Healthy Country National Research Flagship, CSIRO, Melbourne, 2010.

O’Grady, A. P., Carter, J. L., and Bruce, J.: Can we predict groundwater discharge from terrestrial ecosystems using existing ecohydrological concepts?, Hydrol. Earth Syst. Sci., 15, 3731-3739, doi:10.5194/hess-15-3731-2011, 2011.

Oishi, A. C., Oren, R., and Stoy, P. C.: Estimating components of forest evapotranspiration: A footprint approach for scaling sap flux measurements, Agr. Forest Meteorol., 148, 1719-1732, doi:10.1016/j.agrformet.2008.06.013, 2008.

Orellana, F., Verma, P., Loheide, S. P., and Daly, E.: Monitoring and modelling water-vegetation interactions in groundwater-dependent ecosystems, Rev. Geophys., 50, Rg3003, doi:10.1029/2011rg000383, 2012.

Ortuno, M. F. and Garcia-Orellana, Y.: Stem and leaf water potentials, gas exchange, sapflow and trunk diameter fluctuation for detecting water stress in lemon trees, Trees, 20, 1-8, 2006.

Osmond, C. B., Austin, M. P., Berry, J. A., Billings, W. D., Boyer, J. S., Dacey, J. W. H., Nobel, P. S., Smith, S. D., and Winner, W. E.: Stress physiology and the distribution of plants, Bioscience, 37, 38-47, 1987.

Perez-Valdivia, C. and Sauchyn, D.: Tree-ring reconstruction of groundwater levels in Alberta, Canada: Long term hydroclimatic variability, Dendrochronologia, 29, 41-47, doi:10.1016/j.dendro.2010.09.001, 2011.

Perkins, S. P. and Sophocleous, M.: Development of a comprehensive watershed model applied to study stream yield under drought conditions, Ground Water, 37, 418-426, 1999.

Pert, P. L., Butler, J. R. A., Brodie, J. E., Bruce, C., Honzak, M., Kroon, F. J., Metcalfe, D., Mitchell, D., and Wong, G.: A catchment-based approach to mapping hydrological ecosystem services using riparian habitat: A case study from the Wet Tropics, Australia, Ecolog. Complex., 7, 378-388, doi:10.1016/j.ecocom.2010.05.002, 2010.

Peters, E., Torfs, P. J., Van Lanen, H. A., and Bier, G.: Propagation of drought through groundwater - A new approach using linear reservoir theory, Hydrol. Process., 17, 3023-3040, doi:10.1002/hyp.1274, 2003.

Phillips, D. L. and Gregg, J. W.: Source partitioning using stable isotopes: coping with too many sources, Oecologia, 136, 261269, 2003.

Pockman, W. and Sperry, J.: Vulnerability to xylem cavitation and the distribution of Sonoran desert vegetation, Am. J. Bot., 87, 1287-1299, 2000.

Post, V. E. A. and von Asmuth, J. R.: Review: Hydraulic head measurements-new technologies, classic pitfalls, Hydrogeol. J., 21, 737-750, doi:10.1007/s10040-013-0969-0, 2013.

Potts, D. L. and Williams, D. G.: Response of tree ring holocellulose $\delta^{13} \mathrm{C}$ to moisture availability in Populus fremontii at perennial and intermittent stream reaches, W. N. Am. Natural., 64, 27-37, 2004.

Prior, L. D., Grierson, P. F., McCaw, W. L., Tng, D. Y. P., Nichols, S. C., and Bowman, D.: Variation in stem radial growth of the Australian conifer, Callitris columellaris, across the world's driest and least fertile vegetated continent, Trees Struct. Funct., 26, 1169-1179, doi:10.1007/s00468-012-0693-8, 2012.

Querejeta, J. I., Estrada-Medina, H., Allen, M. F., and JiménezOsornio, J. J.: Water source partitioning among trees growing on shallow karst soils in a seasonally dry tropical climate, Oecologia, 152, 26-36, 2007.

Rodell, M. and Famiglietti, J. S.: Terrestrial water storage variations over Illinois : Analysis of observations and implications for Gravity Recovery and Climate Experiment (GRACE), Water Resour. Res., 37, 1327-1340, 2001.

Rodell, M., Chen, J. L., Kato, H., Famiglietti, J. S., Nigro, J., and Wilson, C. R.: Estimating groundwater storage changes in the Mississippi River basin (USA) using GRACE, Hydrogeol. J., 15, 159-166, 2007.

Rodell, M., Velicogna, I., and Famiglietti, J. S.: Satellite-based estimates of groundwater depletion in India, Nature, 460, 999-1002, 2009.

Roderick, M. L. and Farquhar, G. D.: Water availability and evapotranspiration in the Murray Darling Basin: A look at the past and a glimpse into the future, Murray-Darling Basin Authority, Canberra, 2009.

Rood, S. B., Patino, S., Coombs, K., and Tyree, M.: Branch sacrifice: cavitation-associated drought adaptation of riparian cottonwoods, Trees Struct. Funct., 14, 248-257, 2000.

Rood, S. B., Braatne, J., and Hughes, F.: Ecophysiology of riparian cottonwoods: stream flow dependency, water relations and restoration, Tree Physiol., 23, 1113-1124, 2003.

Rood, S. B., Goater, L. A., Gill, K. M., Braatne, J. H.: Sand and sandbar willow: A feedback loop amplifies environmental sensitivity at the riparian interface, Oecologia, 165, 31-40, 2011.

Rossini, M., Cogliati, S., Meroni, M., Migliavacca, M., Galvagno, M., Busetto, L., Cremonese, E., Julitta, T., Siniscalco, C., Morra di Cella, U., and Colombo, R.: Remote sensing-based estimation of gross primary production in a subalpine grassland, Biogeosciences, 9, 2565-2584, doi:10.5194/bg-9-2565-2012, 2012. 
Sala, A., Devitt, D. A., and Smith, S. D.: Water use by Tamarix ramosissima and associated phreatophytes in a Mojave Desert floodplain, Ecol. Appl., 6, 888-898, 1996.

Sarris, D., Christodoulakis, D., and Korner, C.: Recent decline in precipitation and tree growth in the eastern Mediterranean, Global Change Biol., 13, 1187-1200, doi:10.1111/j.13652486.2007.01348.x, 2007.

Scanlon, B. R., Longuevergne, L., and Long, D.: Ground referencing GRACE satellite estimates of groundwater storage changes in the California Central Valley, USA, Water Resour. Res., 48, W04520, doi:10.1029/2011WR011312, 2012a.

Scanlon, B. R., Faunt, C. C., Longuevergne, L., Reedy, R. C., Alley, W. M., McGuire, V. L., and McMahon, P. B.: Groundwater depletion and sustainability of irrigation in the US High Plains and Central Valley, P. Natl. Acad. Sci., 109, 9320-9325, 2012b.

Schilling, K. E. and Zhang, Y. K.: Temporal scaling of groundwater level fluctuations near a stream, Ground Water, 50, 59-67, doi:10.1111/j.1745-6584.2011.00804.x, 2012.

Scott, M. L., Shafroth, P. B., and Auble, G. T.: Responses of riparian cottonwoods to alluvial water table declines, Environ. Manage., 23, 347-358, 1999.

Scott, R. L., Shuttleworth, W. J., Goodrich, D. C., and Maddock, T.: The water use of two dominant vegetation communities in a semiarid riparian ecosystem, Agr. Forest Meteorol., 105, 241256, 2000

Scott, R. L., Edwards, E., Shuttleworth, W., Huxman, T., Watts, C., and Goodrich, D.: Interannual and seasonal variation in fluxes of water and carbon dioxide from a riparian woodland ecosystem, Agr. Forest Meteorol., 122, 65-84, 2004.

Scott, R. L., Huxman, T. E., Cable, W. L., and Emmerich, W. E.: Partitioning of evapotranspiration and its relation to carbon dioxide exchange in a Chihuahuan Desert shrubland, Hydrol. Process., 20, 3227-3243, 2006a.

Scott, R. L., Huxman, T. E., Williams, D. G., and Goodrich, D. C.: Ecohydrological impacts of woody-plant encroachment: seasonal patterns of water and carbon dioxide exchange within a semiarid riparian environment, Global Change Biol., 12, 311324, doi:10.1111/j.1365-2486.2005.01093.x, 2006b.

Scott, R. L., Cable, W. L., Huxman, T. E., Nagler, P. L., Hernandez, M., and Goodrich, D. C.: Multiyear riparian evapotranspiration and groundwater use for a semiarid watershed, J. Arid Environ., 72, 1232-1246, 2008.

Scurlock, D.: From the Rio to the Sierra: An Environmental History of the Middle Rio Grande Basin, General Technical Report RMRS-GTR-5, USDA Forest Service, Rocky Mountain Research Station, Fort Collins, CO, 1998.

Seckler, D., Barker, R., and Amarasinghe, U.: Water scarcity in the twenty-first century, Int. J. Water Res. Dev., 15, 29-42, 1999.

Shafroth, P. B., Cleverly, J. R., Dudley, T. L., Taylor, J. P., Van Riper, C., Weeks, E. P., and Stuart, J. N.: Control of Tamarix in the Western United States: Implications for water salvage, wildlife use, and riparian restoration, Environ. Manage., 35, 231-246, 2005

Shah, J. J. F. and Dahm, C. N.: Flood regime and leaf fall determine soil inorganic nitrogen dynamics in semiarid riparian forests, Ecol. Appl., 18, 771-788, 2008.

Shah, N., Nachabe, M., and Ross, M.: Extinction depth and evapotranspiration from ground water under selected land covers. Ground Water, 45, 329-338, 2007.
Shiklomanov, I. A.: World water resources: A new appraisal and assessment for the 21st century, United Nations Educational, Scientific and Cultural Organisation, St. Petersburg, Russia, 2008.

Smith, S. D., Devitt, D. A., Sala, A., Cleverly, J. R., and Busch, D. E.: Water relations of riparian plants from warm desert regions, Wetlands, 18, 687-696, 1998.

Soylu, M. E., Lenters, J. D., Istanbulluoglu, E., and Loheide II, S. P.: On evapotranspiration and shallow groundwater fluctuations: A Fourier-based improvement to the White method, Water Resour. Res., 48, W06506, doi:10.1029/2011wr010964, 2012.

Sperry, J. S., Meinzer, F. C., and McCulloh, K. A.: Safety and efficiency conflicts in hydraulic architecture: scaling from tissues to trees, Plant Cell Environ., 31, 632-645, 2008.

Stock, W. D., Bourke, L., and Froend, R. H.: Dendroecological indicators of historical responses of pines to water and nutrient availability on a superficial aquifer in south-western Australia, Forest Ecol. Manage., 264, 108-114, 2012.

Stromberg, J. C., Tiller, R., and Richter, B.: Effects of groundwater decline on riparian vegetation of semiarid regions: The San Pedro, Arizona, Ecol. Appl., 6, 113-131, 1996.

Stromberg, J. C., Lite, S. J., Rychener, T. J., Levick, L. R., Dixon, M. D., and Watts, J. M.: Status of the riparian ecosystem in the upper San Pedro River, Arizona: Application of an assessment model, Environ. Monit. Assess., 115, 145-173, 2006.

Stromberg, J. C., Beauchamp, V. B., Dixon, M. D., Lite, S. J., and Paradzick, C.: Importance of low-flow and high-flow characteristics to restoration of riparian vegetation along rivers in and southwestern United States, Freshwater Biol., 52, 651-679, 2007.

Stromberg, J. C., Lite, S. J., and Dixon, M. D.: Effects of stream flow patterns on riparian vegetation of a semiarid river: implications for a changing climate, River Res. Appl., 26, 712-729, doi:10.1002/rra.1272, 2010.

Sun, A. Y.: Predicting groundwater level changes using GRACE data, Water Resour. Res., 49, 5900-5912, doi:10.1002/wrcr.20421, 2013.

Syed, T. H., Famiglietti, J. S., and Chambers, D. P.: GRACEbased estimates of terrestrial freshwater discharge from basin to continental scales, J. Hydrometeorol., 10, 22-40, doi:10.1175/2008JHM993.1, 2009.

Tapley, B. D., Bettadpur, S., Watkins, M., and Reigber, C.: The gravity recovery and climate experiment: Mission overview and early results, Geophys. Res. Lett., 31, L09607, doi:10.1029/2004GL019920, 2004.

Thorburn, P. J., Walker, G. R., and Woods, P. H.: Comparison of diffuse discharge from shallow-water tables in soils and salt flats, J. Hydrol., 136, 253-274, 1992.

Thorburn, P. J., Hatton, T., and Walker, G. R.: Combining measurements of transpiration and stable isotopes to determine groundwater discharge from forests, J. Hydrol., 150, 563-587, 1993.

Tweed, S. O., LeBlanc, M., Webb, J. A., and Lubczynski, M. W.: Remote sensing and GIS for mapping groundwater recharge and discharge areas in salinity prone catchments, southeastern Australia, Hydrogeol. J., 15, 75-96, 2007.

van Hylckama, T. E. A.: Water use by salt cedar, Water Resour. Res., 6, 728-735, 1970

Wada, Y., Van Beek, L. P. H., Van Kempen, C. M., Reckman, J. W. T. M., Vasak, S., and Bierkens, M. F. P.: Global depletion of groundwater resources, Geophys. Res. Lett., 37, L20402, doi:10.1029/2010g1044571, 2010. 
Wang, P., Zhang, Y. C., Yu, J. J., Fu, G. B., and Ao, F.: Vegetation dynamics induced by groundwater flucturations in the lower Heihe River Basin northwestern China, J. Plant Ecol., 4, 77-90, 2011.

Wang, P., Yu, J. J., Pozdniakov, S. P., Grinevsky, S. O., and Liu, C. M.: Shallow groundwater dynamics and its driving forces in extremely arid areas: a case study of the lower Heihe River in northwestern China, Hydrol. Process., 28, 1539-1553, doi:10.1002/hyp.9682, 2014.

White, W. N.: A method of estimating ground-water supplies based on discharge by plants and evaporation from soil: Results of investigations in Escalante Valley, Utah, in: Interior, US Geological Survey, Washington, D.C., p. 105, 1932.

Whitley, R. and Eamus, D.: How much water does a woodland or plantation use: a review of some measurement methods, Land \& Water Australia, Canberra, 2009.

Wilcox, L. J., Bowman, R. S., and Shafike, N. G.: Evaluation of Rio Grande management alternatives using a surface-water/groundwater model, J. Am. Water Resour. As., 43, 1595-1603, 2007.

Wright, I. J., Groom, P. K., Lamont, B. B., Poot, P., Prior, L. D., Reich, P. B., Schulze, E. D., Veneklaas, E. J., and Westoby, M.: Leaf trait relationships in Australian plant species, Funct. Plant. Biol., 31, 551-558, 2004.

Xiao, S. C., Xiao, H. L., Peng, X. M., and Tian, Q. Y.: Intra-annual stem diameter growth of Tamarix ramosissima and association with hydroclimatic factors in the lower reaches of China's Heihe River, J. Arid Land, 6, 498-510, doi:10.1007/s40333-013-0248$\mathrm{x}, 2014$.

Yang, H., Yang, D., Lie, Z., and Sun, F.: New analytical derivation of the mean annual water energy balance equation, Water Resour. Res., 44, W03410, doi:10.1029/2007WR006135, 2008.
Yang, X., Smith, P. L., Yu, T., and Gao, H.: Estimating ET from terrestrial GDEs using Landsat images, Int. J. Dig. Earth., 4, 154170, 2011.

Yuan, W. P, Liu, S. G., Yu, G. R., Bonnefond, J. M., Chen, J. Q., Davis, K., Desai, A. R., Goldstein, A. H., Gianelle, D., Rossi, F., Suyker, A. E., and Verma, S. B.: Global estimates of evapotranspiration and gross primary production based on MODIS and global meteorology data, Remote Sens. Environ., 114, 14161431, doi:10.1016/j.rse.2010.01.022, 2010.

Zencich, S. J., Froend, R. H., Turner, J. V., and Gailitis, V.: Influence of groundwater depth on the seasonal sources of water accessed by Banksia tree species on a shallow, sandy coastal aquifer, Oecologia, 131, 8-19, 2002.

Zeppel, M.: Convergence of tree water use and hydraulic architecture in water-limited regions: a review and synthesis, Ecohydrology, 6, 889-900, 2013.

Zhang, L., Hickel, K., Dawes, W. R., Cheiw, F. H. S., Western, A. W., and Briggs, P. R.: A rational function approach for estimating mean annual evapotranspiration, Water Resour. Res., 40, W02502, doi:10.1029/2003WR002710, 2004.

Zinko, U., Seibert, J., Merritt, D. M., Dynesius, M., and Nilsson, C.: Plant species numbers predicted by a topography-based groundwater flow index, Ecosystems, 8, 430-441, 2005.

Zolfaghar, S.: Comparative ecophysiology of Eucalyptus woodlands along a depth-to-groundwater gradient, $\mathrm{PhD}$ thesis, University of Technology, Sydney, 228 pp., 2014.

Zunzunegui, M., Barradas, M. C. D., and Novo, F. G.: Different phenotypic responses of Halimium halimifolium in relation to groundwater availability, Plant Ecol., 148, 165-174, 2000.

Zweifel, R., Zimmermann, L., and Newbery, D. M.: Modelling tree water deficit from microclimate: an approach to quantifying drought stress, Tree Physiol., 25, 147-156, 2005. 